\title{
固液複合系の力学物性
}

\author{
武井康子*
}

\section{A Review of the Mechanical Properties of Solid-liquid Composites}

\author{
Yasuko TAKEI *
}

\begin{abstract}
This article reviews the mechanical properties of solid-liquid composites with special emphasis on acoustic properties. A simple method proposed by Takei (2002) to estimate porosity, pore shape, and/or liquid compressibility from data on elastic wave velocities $\left(V_{P}\right.$ and $\left.V_{S}\right)$ is summarized. Using this method, a variety of pore shapes are treated systematically in terms of the equivalent aspect ratio of an oblate spheroid model. An important application of this method is in the detection of terrestrial fluids from seismic tomographic images. Information on pore shape obtained from tomographic images is shown to provide valuable information on the migration of aqueous fluids and melts in the Earth's interior. A brief summary is also presented on dispersion and attenuation mechanisms in solid-liquid composite media to clarify the assumptions and the limitations of the present method.
\end{abstract}

Key words : solid-liquid composite, elastic wave velocity, tomography, water, melt, poroelasticity キーワード：固液複合系，弾性波速度，トモグラフィー，水，メルト，多孔質媒質理論

\section{I. はじめに}

地球内部における水やメルトなどの流体相の生 成と移動の様式を解明することは，古くから固体 地球科学における大きな関心事の一つであった。 火山地域では，マグマの活動と密接に関連して微 動や低周波地震などの特異な地震が発生すること が良く知られてきた。近年, 火山活動と直接関連 のない場所でも流体の存在を示唆する微動や低周 波地震活動が発見され, 地球内部の流体活動へ の関心が高まっている (e.g., Obara, 2002; Ohmi and Obara, 2002)。最近の地震観測網の発達に より, 地下の 3 次元地震波速度構造や減衰構造 が高解像度で得られるようになり，水やメルトの
存在する領域を地震波の低速度域や高隇衰域とし てとらえることができるようになってきた（e.g., Nakajima et al.; 2001a, b, 2003; Tsumura et al., 2000）。流体はそれ自体では横波速度が 0 である が, 低速度域の横波速度は 0 ではない。このこ とから，地震波がとらえているものが，固体と流 体の混ざり合う固液複合系としての流体の姿であ ることがわかる。地震波を用いた観測から対象と する固液複合系の状態について有用な情報を引き 出すためには, 固液複合系の力学物性についての 知識が必要となる。

固液複合系の特徵を表す最も一般的なパラメー 夕は流体の体積分率である。流体の体積分率が小 さいほど固体の物性に近く, 大きいほど液体の

* 東京大学地震研究所

* Earthquake Research Institute, University of Tokyo 
物性に近くなるという傾向が一般にある。しか し, 流体の体積分率に加えて, 流体ポアの形状が 系の力学物性に大きな影響を与える。力学物性に 対するポア形状の影響の強さは，固体と固体の混 合物や液体と液体の混合物に比べて固液複合系を 特徵付ける性質の一つである。これまで, 固液複 合系の力学物性について, 様々なポア形状を仮定 したモデルが提案されてきた（e.g., Kuster and Toksöz, 1974; O'Connell and Budiansky, 1974; Mavko, 1980; Takei, 1998)。ポア形状が既知の 系の力学物性を予測するためには，このような フォーワードアプローチのみで良い。しかし多く の観測や実験では, 対象とする固液複合系のポア 形状が未知である。このようなデー夕を解析する ためには，特定のポア形状を仮定したフォーワー ドアプローチから得られる断片的な知識のみでは 不十分で，ポア形状の影響を系統的に理解するこ とが重要である。ある特定の力学物性への影響が 等しいポア形状同士を結びつける「等価アスペク 卜比」という概念を用いると，ポア形状を系統的 に扱うことが可能になる (Takei, 2002)。本総説 の目的は, 等価アスペクト比の概念を用いて, 固 液複合系の弾性波速度に与える流体の体積分率, ポア形状，そして流体の物性の影響を系統的に整 理すること，そして，これらの性質を弾性波速度 デー夕の逆解析によってどの程度知り得るかを明 確にすることである。

II 章ではまず固液複合系のマクロな力学物性や ダイナミクスを扱うための理論的枠組みを紹介す る。固液複合系の波動伝播を扱うための理論的枠 組みは Biot $(1956 \mathrm{a}, \mathrm{b})$ により与えられているが, この理論は均質な系の微小変形のみに限定され, 不均質のある場合や大変形への拡張性がそしい。 本総説では，波動伝播の問題のみならず，固液複 合系の様々なダイナミクスを取り扱う際の基礎と なる拡張性の高い枠組みを紹介する。II 章で紹介 する理論的枠組みを而章で均質な系の微小変形に 適用して簡単化し, 固液複合系の波動方程式を導 く。IV-V 章では固液複合系の弾性波速度に対す る流体の体積分率, ポア形状, 流体物性の影響を 詳しく議論し, V章ではその地球科学的重要性を
述べる。四章では固液複合系における弾性波の分 散と減衰について簡単なまとめを行い, 本総説で 扱った弾性波速度の適用範囲を明らかにする。本 総説で用いる「液体」は「流体」とほぼ同じ意味 であるので，気体も含めて考えることができる。

\section{II. 固液複合系のマクロなダイナミクスを 扱う理論的枠組み}

初めに固液複合系のマクロなダイナミクスを扱 う理論的枠組みを紹介する。図 1aに固液複合系 の例を示す。固体粒子のサイズより小さいスケー ルをミクロスケールと呼ぶことにする。固体中と 液体中では密度場, 変位場, 応力場, などが異 なるため, この系の力学場はミクロスケールでも 不均質である。しかし，このような系に対する地 球科学的な興味は, もっぱら, 粒子サイズより十 分波長の長い弾性波動伝播や部分溶融領域からの マントルスケールでのメルトの分離上昇過程のよ うな，スケールの大きな現象にある。このような マクロスケールのダイナミクスは，以下に示すよ うに，ミクロスケールの不均質を平均化して得ら れるマクロな変数のみに基づいて一般の連続体力 学と同様に取り扱うことができる。その際，固体 の平均と液体の平均とを分けて取り扱うことによ り,メルトの分離上昇過程のような固体と液体が 異なる運動をする現象をも取り扱うことができ, 理論の応用範囲が広くなる。多孔質媒質理論と呼 ばれるものもここで紹介する理論に含まれるが, 均質な系の微小変形を前提としているため理論の 適用範囲に制限がある。また多孔質媒質理論に関 する文献の多くは，歴史的経緯や応用への配慮か ら説明が複雑になっており, 必要最小限の知識が 見えにくい。この章では, 系に対する必要最小限 の要請が, 通常の連続体力学々同様に, 質量保存 則, 運動量保存則, および構成則の要請であるこ とを確認する。

固液複合系のマクロな座標 $\mathbf{x}$ の位置に REV (representative elementary volume) と呼ぶ小 領域を考える（図 $1 \mathrm{a}, \mathrm{b}$ )。REV は十分な数の固 体粒子を含む大きさにとる。変位場や応力場など の力学場について, REV 内での平均をとった量 
(a)
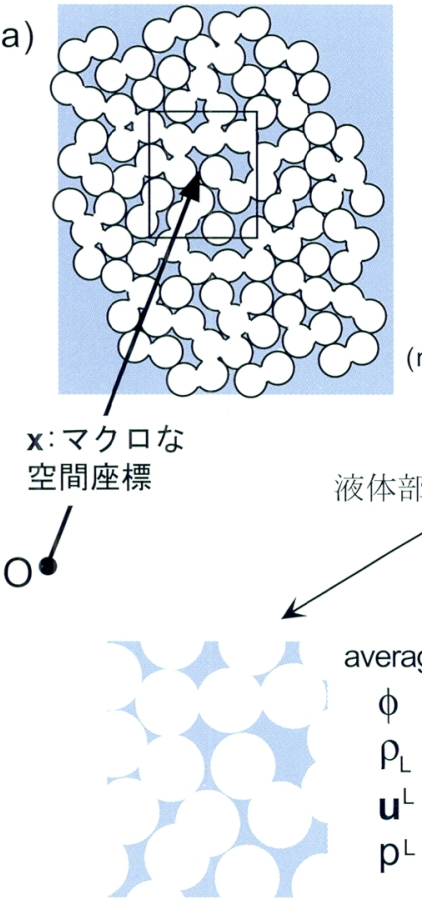

(c) (b)

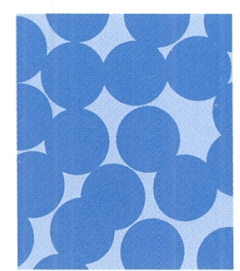

REV

(representative elementary volume)
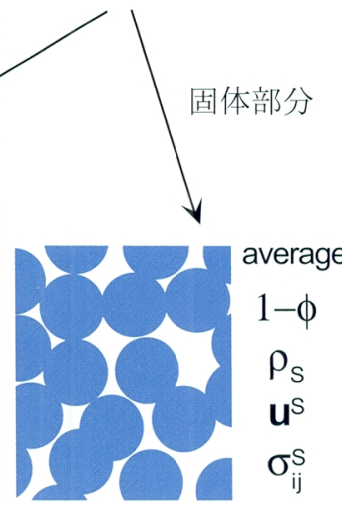

(d)
図 1 固液複合系のマクロなダイナミク 又を記述する理論的枠組み。

(a) マクロな座標 $\mathbf{x}$ の位置に, 四 角で示す小領域 REV(representative elementary volume）を考える。(b) $\mathrm{REV}$ の拡大四（薄色が液体，濃色 が固体). (c) REV内の液体部分 とその力学場の平均. (d) REV 内 の固体部分とその力学場の平均。

Fig. 1 (a), (b) Representative elementary volume (REV) defined in a solidliquid composite system. (c), (d) Liquid and solid systems in REV and the average of their mechanical fields.
（マクロな量）を定義する。その際，液相におけ る平均（図 1c）と固相における平均（図 1d）と を区別して考える。即ち，REVに含まれる液体 の体積分率を $\phi$, 平均密度を $\rho_{L}$, 平均変位を $\mathbf{u}^{L}$, 平均圧力を $p^{L}$ とする。また, $\mathrm{REV} に$ 含まれる固 体の体積分率を $1-\phi$, 平均密度を $\rho_{S}$, 平均変 位を $\mathbf{u}^{S}$, 平均応力を $\sigma_{i j}^{S}$ とする。このように, 位 置 $\mathbf{x}$ における系の力学状態を,

$$
\begin{aligned}
& \phi \ldots . . . \text { 液体の体積分率 }(\text { 無次元 }) \\
& \rho_{L} \ldots . \text { 液体の密度 }\left(\mathrm{kg} / \mathrm{m}^{3}\right) \\
& \rho_{S} \ldots . \text { 固体の密度 }\left(\mathrm{kg} / \mathrm{m}^{3}\right) \\
& \mathbf{u}^{L} \ldots . . \text { 液体の変位 }(\mathrm{m}) \\
& \mathbf{u}^{S} \ldots . . \text { 固体の変位 }(\mathrm{m}) \\
& p^{L} \ldots . . . \text { 液体の圧力. 押しが正 }(\mathrm{Pa}) \\
& \sigma_{i j}^{S} \ldots . . \text { 固体の応力. 引きが正 }(\mathrm{Pa})
\end{aligned}
$$

という 7 つマクロな独立変数によって記述す ることがこの理論の特徴である。

7 つの変数の振る舞いは, 以下の 7 つの基礎方
程式により記述される。

(A) 液体の質量保存則

$$
\frac{\partial\left(\phi \rho_{L}\right)}{\partial t}+\nabla \cdot\left(\phi \rho_{L} \dot{\mathbf{u}}^{L}\right)=\Gamma
$$

(B) 固体の質量保存則

$$
\frac{\partial\left\{(1-\phi) \rho_{S}\right\}}{\partial t}+\nabla \cdot\left\{(1-\phi) \rho_{S} \dot{\mathbf{u}}^{S}\right\}=-\Gamma
$$

(C) 液体本来の構成則

$$
\frac{\delta \rho_{L}}{\rho_{L}}=\frac{1}{k_{L}} \delta p^{L}
$$

(D) 固体本来の構成則

$$
\frac{\delta \rho_{S}}{\rho_{S}}=\frac{1}{k_{S}} \delta p^{S}
$$

(E) 固体フレームワークの構成則

$$
\begin{aligned}
\epsilon_{i j}= & \frac{1}{2 N}\left(\sigma_{i j}^{\prime}-\frac{\sigma_{k k}^{\prime}}{3} \delta_{i j}\right)+\frac{1}{3 K_{b}} \frac{\sigma_{k k}^{\prime}}{3} \delta_{i j} \\
& -\frac{1}{3 k_{S}} p^{L} \delta_{i j}
\end{aligned}
$$


（F）液体の運動量保存則

$$
\phi \rho_{L} \ddot{\mathbf{u}}^{L}=-\nabla\left(\phi p^{L}\right)+\phi \rho_{L} \mathbf{g}+\mathbf{I}
$$

(G) 固体の運動量保存則

$$
\begin{aligned}
(1-\phi) \rho_{S} \ddot{\mathbf{u}}^{S} & =\nabla \cdot\left\{(1-\phi) \sigma^{S}\right\} \\
& +(1-\phi) \rho_{S} \mathbf{g}-\mathbf{I}
\end{aligned}
$$

(F) - $(\mathrm{G})$ に含まれる I は, 固体と液体の相互作 用（固体が液体に及ぼす力を正， $\mathrm{N} / \mathrm{m}^{3}$ ) を表し， 具体的には，

$$
\text { (*) } \mathbf{I}=-\frac{\eta \phi^{2}}{k_{\phi}}\left(\dot{\mathbf{u}}^{L}-\dot{\mathbf{u}}^{S}\right)+p^{L} \nabla \phi
$$

と与えられる。ただし，以上の方程式において，

$\Gamma \ldots .$. 固体から液体への相変化 $\left(\mathrm{kg} / \mathrm{s} / \mathrm{m}^{3}\right)$

$k_{L} \ldots \ldots$ 液体本来の体積弾性率 $(\mathrm{Pa})$

$k_{S} \ldots . .$. 固体本来の体積弾性率 $(\mathrm{Pa})$

$K_{b} \ldots .$. 固体スケルトンの体積弾性率 $(\mathrm{Pa})$

$N \ldots \ldots$ 固体スケルトンの剛性率 $(\mathrm{Pa})$

$\eta$...... 液体の粘性率 $(\mathrm{Pa} \mathrm{s})$

$k_{\phi} \ldots . .$. 浸透率 $\left(\mathrm{m}^{2}\right)$

$p^{S}=-\frac{1}{3}\left(\sigma_{x x}^{S}+\sigma_{y y}^{S}+\sigma_{z z}^{S}\right)$

……固体の圧力. 押しが正 $(\mathrm{Pa})$

$\epsilon_{i j}=\frac{1}{2}\left(\frac{\partial u_{i}^{S}}{\partial x_{j}}+\frac{\partial u_{j}^{S}}{\partial x_{i}}\right)$

……固体フレームワークの歪み (無次元)

$\sigma_{i j}=(1-\phi) \sigma_{i j}^{S}-\phi p^{L} \delta_{i j}$

...... 媒質に働くバルクの応力. 引きが正 $(\mathrm{Pa})$

$\sigma_{i j}^{\prime}=\sigma_{i j}+p^{L} \delta_{i j} \ldots .$. 有効応力 $(\mathrm{Pa})$

$\mathrm{g}$....... 重力加速度ベクトル $(\mathrm{N} / \mathrm{kg})$

$\dot{\mathbf{u}}=D \mathbf{u} / D t$ は速度, $\ddot{\mathbf{u}}=D \dot{\mathbf{u}} / D t$ は加速度

$\nabla p^{L}=\operatorname{grad} p^{L}=\partial p^{L} / \partial x_{i}$

$\nabla \cdot \dot{\mathbf{u}}=\operatorname{div} \dot{\mathbf{u}}=\partial \dot{u}_{i} / \partial x_{i}($ 総和規約を適用 $)$

$\nabla \cdot \sigma=\partial \sigma_{i j} / \partial x_{j}=\sigma_{i j, j}($ 総和規約を適用)

である。

ミクロスケールに見ると，固相液相それぞれの 相内で質量保存則, 運動量保存則, 構成則が厳密 に成り立つことが要請される。これらの要請を REV 内の各相について積分することにより，上 に挙げた 7 つ基礎方程式のうち固体フレーム ワークの構成則 $(\mathrm{E})$ 以外の 6 つを導くことがで きる（Drew, 1983）。基礎方程式の（A)-(D)に

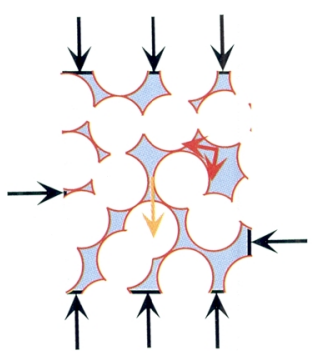

液体部分に働く力

(a)

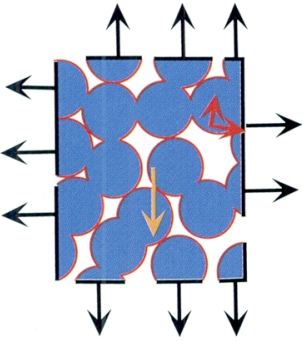

固体部分に働く力

(b)
図 2 (a) REV 内の液体部分に働く力. (b) REV 内の固体部分に働く力.

系の全境界を，REVの表面に一致する境 界（黒で示す）と固液界面に一致する境界 (赤)に分け，それぞれの境界を通して働 く力を同色で示した（液压は押しを正，固 体の応力は張力を正とする). 赤の力は, 界面に平行な成分と垂直な成分に分けて 示した。体積力（重力）はオレンジ色で示 した。

Fig. 2 Forces applied to liquid (a) and solid (b) systems in REV.

Black arrows: surface force applied through the boundary of REV (black). Red arrows: surface force applied through the boundary with the other phase (red). Orange arrows: body force applied by gravity. Stress is tension positive and liquid pressure is compression positive.

ついては，流体力学で一般的に用いられている基 礎方程式との比較からその意味が容易に理解でき るであろう。(A), (B) の右辺の「は, 固体と液 体の間で相変化が起こる場合にのみ 0 でない值 を持つ。ここでは $(\mathrm{E})-(\mathrm{G})$ 式について，その意 味と導出法をやや詳しく説明する。

運動量保存則 $(\mathrm{F}),(\mathrm{G})$ の各項の意味を理解 するための説明を図 2 に示す。REV内の固体ま たは液体に働く力は, 体積力である重力と, 領域 の境界を通して働く面積力との二つに分けられ る。一方, 領域の境界は, REVの箱の表面に一 致する境界（黒で示してある）と固相と液相の相 境界に一致する境界 (赤で示してある) の二つに 分けられる。黑の境界は同じ相内に，赤の境界は 二相の境界にある。黑の境界から受ける力の合力 は $(\mathrm{F})-(\mathrm{G})$ の右辺第一項により与えられるが, 
これらの項は通常の連続体力学の式からの類推で 容易に理解できる。一方，赤の境界を通して働く 力は二相系に特徴的な力で, その合力 $\mathbf{I}$ は作用反 作用の法則から $(\mathrm{F}) ，(\mathrm{G})$ で符号が逆になる。I の具体的な内訳を $(*)$ に示したが, 第一項は固 液の相対速度による粘性引きずりの力を，第二項 は液体の圧力からの寄与を表している。赤の境界 面に働く力のうち, 界面に平行な成分のみの合 計を示したものが（*）の第一項で，界面に垂直 な成分のみの合計を示したものが (*) の第二項 であると考えることができる（図 3$) 。(F) ，(G)$ を導出する際に，固体も液体もそれぞれ空間的に つながっていることを前提とした（図 2 ，黒の境 界面)。従って, 例えば固体の粒が液体に分散し ている系（サスペンジョン）や，液体が固体に分 散している系（インクルージョン）へ適用する際 には注意が必要である。

(E) 式左辺の $\epsilon_{i j}$ は，ただし書きに示すように 固体のマクロな変位場 $\mathbf{u}^{S}$ の空間微分（即ち, 歪 み）により定義され，固体フレームワークの歪み と呼ぶ。例えばスポンジをギュッと縮めることを 考えると, スポンジのマクロな変形を表すのがこ の的であり，これをスポンジに加わるマクロな (平均化された) 応力に関係付ける式が (E) 式 である。スポンジは柔らかく弱い力で大きく変形 するが，このようなマクロに見えるスポンジの性 質を記述するのが（E）式である。（E）式を導出 する方法を図 4 に示す。固体には黒の境界面を 通して $\sigma_{i j}^{S}$ の応力, 赤の境界面を通して $p^{L} の$ 液压 が加わっている（図 4a)。この時の固体フレーム ワークの歪みを, 黒の境界面に $\sigma_{i j}^{S}+p^{L} \delta_{i j}$ の応 力が加わり赤の境界面は自由表面になっている場 合（図 4b）の歪みと，すべての境界に一定の压 力 $p^{L}$ (すなわち応力 $-p^{L} \delta_{i j}$ ) が加わった場合（図 $4 \mathrm{c})$ の歪みとの和として計算できると仮定する(固 体本来の物性が線形であれば，このような足し合 わせができる)。相境界面が自由表面になってい る時（図 4b）の固体フレームワークを特に「ス ケルトン」と呼び，その弾性的性質は“スケルト ンの体積弾性率 $K_{b}$ ” と“スケルトンの剛性率 $N$ ” により表される（E式の右辺第 1 項，第 2 項）。

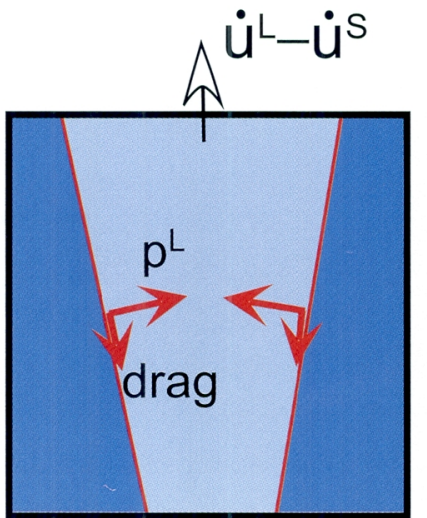

図 3 固液界面 (赤) を通して働く固体と液体の 相互作用の内訳（ポロシティに空間勾配の ある場)。

界面に平行な力は固液の粘性引きずりで 生じると考え, その合力は固液のマクロ な相対速度に比例すると仮定する。界面 に垂直な力は液圧に等しいと考えると， その合力はポロシティの空間勾配に比例 する。固体から液体に働く力のみ赤矢印 で示した。

Fig. 3 Schematic illustration of the interaction between solid and liquid under a gradient of porosity.

スポンジが柔らかいという例からも分かるよう に， $K_{b}$ と $N$ は固体物質本来の弾性定数のみでは 決まらずに，ポロシティやポア形状に大きく依存 するものであることに注意が必要である。(ポロ シティは液体の体積分率 $\phi$ と同じになるが，スケ ルトンを議論する祭にはポロシティという言葉を 用いることにする。）すべての境界に一様な圧力 $p^{L}$ が動く時（図 4c）の固体フレームワークの振 る舞いは, REV内がすべて固体で満たされてい る時の振る舞いと等価であり, 固体本来の体積弾 性率 $k_{S}$ で決まる体積変化をする（E式の右辺第 3 項)。

（E）を導出する祭に，固体が弾性体の場合の みを考えたが，例えば部分溶融層からの固液分離 過程のようなゆっくりした現象では，固体は粘性 体として扱われる（e.g., McKenzie, 1984）。この 場合には（E）式は固体スケルトンの体積粘性率 そ（Pa s）拉よび固体スケルトンのせん断粘性率 $\zeta(\mathrm{Pas})$ を用いて， 


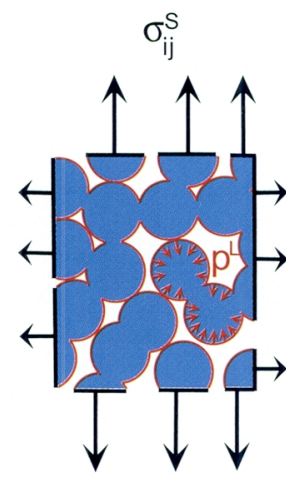

(a)

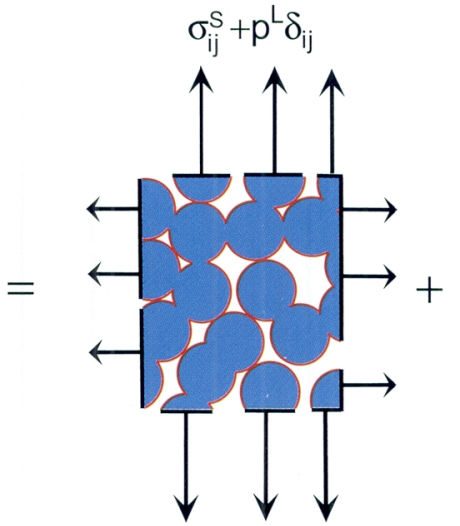

(b)

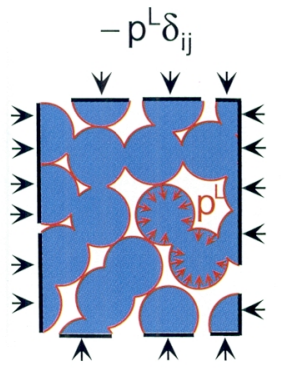

(c)

図 $4 \mathrm{REV}$ 内の固体部分に働く力 (a) を(b) と（c）の二つに分解

（a）黑の境界面を通して応力 $\sigma_{i j}^{S}$ が，赤の境界面を通して液压 $p^{L}$ が加わっている. （b）黑の境界を通して応力 $\sigma_{i j}^{S}+p^{L} \delta_{i j}$ が加わり，赤の境界面は自由表面になっ ている，(c) 全ての境界面に液压 $p^{L}$ (すなわち応力 $-p^{L} \delta_{i j}$ ）が加わっている.

Fig. 4 The constitutive relation for a solid framework (eq.E in the text) can be derived by dividing the applied force (a) into the uniform pressure on all boundaries (c) and the other (b).

$\left(\mathrm{E}^{\prime}\right) \dot{\epsilon}_{i j}=\frac{1}{2 \zeta}\left(\sigma_{i j}^{\prime}-\frac{\sigma_{k k}^{\prime}}{3} \delta_{i j}\right)+\frac{1}{3 \xi} \frac{\sigma_{k k}^{\prime}}{3} \delta_{i j}$

となる。粘性による大変形を扱う際には固体本来 の圧縮性が無視できるため, (E) の右辺第 3 項 に相当する項がない。固体本来の圧縮性が無視で きる場合でも，スケルトンの体積粘性率 $゙$ が無 視できないことには注意が必要である。スポンジ の例からも分かるように，固体本来の物性に圧縮 性がなくてもポアの体積を小さくすることで固体 フレームワークは体積変化し得るからである。

上記では固体フレームワークの歪み $\epsilon_{i j}$ の物理 的意味をスポンジの例で直感的に述べたが， $\epsilon_{i j}$ の数学的側面について少し補足する。固体内の变 位場についてミクロスケールでの空間微分をとる と固体内の歪み場になる。これを $\mathrm{REV}$ 内の固体 で平均したものをここでは「固体の平均歪み」と 呼ぶことにする。固体内のミクロな歪み場とミク 口な応力場は固体物質本来の物性によって関係付 けられるので, 固体の平均歪みと固体の平均応力 との関係は固体物質本来の物性のみで決まる。こ れが $(\mathrm{D})$ 式である。従って $\epsilon_{i j}$ と平均応力の関係
が固体物質本来の物性のみでは決まらないことを 理解するためには, 固体の平均歪みと $\epsilon_{i j}$ の違い を意識することが重要である。数学的には，固体 の平均歪みが「変位場の微分の平均」であるのに 対して $\epsilon_{i j}$ は「変位場の平均の微分」であり, 両 者の違いは積分 (平均) と微分の操作を行う順序 の違いに他ならない。積分と微分の順序は通常は 交換できるが，今のように平均化が REV 内の領 域全体ではなく固体部分のみで行われる場合には, 積分と微分の順序が重要な違いを生むのである。

以上のまとめから, 固液複合系のダイナミクス に直接的な影響を与える物性パラメータは, $\rho_{L}$, $\rho_{S}, k_{L}, k_{S}, \eta, K_{b}, N, k_{\phi}$ であることが分かる。 これらのパラメータのうち, 固体と液体本来の物 性に関しては既存の物性データから制約すること ができる。しかし，スケルトンの体積弾性率 $K_{b}$, スケルトンの剛性率 $N$, および浸透率 $k_{\phi}$ は, 固 体や液体本来の物性では決まらずに，ポロシティ やポア形状によって大きく変わる量である。この ため, 対象とする固液複合系に対してこれら三つ のパラメータが未知である場合が多く, 系のダイ ナミクスを予測するうえでの鍵となることが多 
い。以下の章で扱う弾性波速度の問題では，スケ ルトンの弾性定数 $K_{b}$ と $N$ が鍵となる。

\section{III. 固液複合系の波動方程式}

前章の理論を均質な系の微小変形に適用して理 論を簡単化し, 固液複合系の波動方程式を導出す る。その際, 簡単化された理論が線形多孔質媒質 理論に一致することも確認する。

マクロに均質な媒質では, $\phi, \rho_{L}, \rho_{S}$ の時空 間変化は変位場 $\mathbf{u}^{L}$ と $\mathbf{u}^{S}$ により生じる。従って, $\mathbf{u}^{L}$ と $\mathbf{u}^{S}$ が十分に小さい場合には, $\dot{\mathbf{u}}^{L} \cdot \nabla\left(\phi \rho_{L}\right)$ や $\dot{\mathbf{u}}^{S} \cdot \nabla\left((1-\phi) \rho_{S}\right)$ などの項は二次の微少 量として無視できる。このような近似のもとに， 質量保存則 (A), (B) から (A) $/ \rho_{L}+(\mathrm{B}) / \rho_{S}$ を 計算し，さらに構成則 $(\mathrm{C}),(\mathrm{D})$ を代入すると

$$
\frac{\phi}{k_{L}} \frac{\partial p^{L}}{\partial t}+\frac{1-\phi}{k_{S}} \frac{\partial p^{S}}{\partial t}+\phi \operatorname{div} \dot{\mathbf{u}}^{L}+(1-\phi) \operatorname{div} \dot{\mathbf{u}}^{S}=0
$$

を得る。係数に含まれる $\phi$ の時間変化の寄与は二 次の微少量として無視できるので，(1）式は簡 単に時間積分を行うことができて,

$$
-\phi \operatorname{div}\left(\mathbf{u}^{L}-\mathbf{u}^{S}\right)=\frac{\phi}{k_{L}} p^{L}+\frac{1-\phi}{k_{S}} p^{S}+\operatorname{div} \mathbf{u}^{S}
$$

を得る。この章では以後微少変化を表す $\delta \mathbf{u} や$ $\delta p$ などの表記を簡単に $\mathbf{u}, p$ などと書く。(2) 式で, $\operatorname{div} \mathbf{u}^{S}=\epsilon_{k k}$ の項は（E）式を用いて応力の みで書き表すことができる。こうして得られる式 と（E）式とを並べて書くと

$$
\begin{aligned}
\phi \operatorname{div}\left(\mathbf{u}^{L}-\mathbf{u}^{S}\right)=\phi\left(\frac{1}{k_{S}}-\frac{1}{k_{L}}\right) p^{L} \\
\quad+(1-\phi)\left(\frac{1}{K_{b}}-\frac{1}{k_{S}}\right)\left(p^{S}-p^{L}\right) \\
\epsilon_{i j}=\frac{(1-\phi)}{2 N}\left(\sigma_{i j}^{S}-\frac{\sigma_{k h}^{S}}{3} \delta_{i j}\right) \\
\quad-\frac{(1-\phi)}{3 K_{b}}\left(p^{S}-p^{L}\right) \delta_{i j}-\frac{1}{3 k_{S}} p^{L} \delta_{i j}
\end{aligned}
$$

となる。同様に運動量保存則 $(\mathrm{F})$ と $(\mathrm{G})$ につ いても（*) を代入して重力の項を無視すると,

$$
\phi \rho_{L} \ddot{\mathbf{u}}^{L}=-\phi \nabla \cdot p^{L}-\frac{\eta \phi^{2}}{k_{\phi}}\left(\dot{\mathbf{u}}^{L}-\dot{\mathbf{u}}^{S}\right)
$$

$$
(1-\phi) \rho_{S} \ddot{\mathbf{u}}^{S}=(1-\phi) \nabla \cdot \sigma^{S}+\frac{\eta \phi^{2}}{k_{\phi}}\left(\dot{\mathbf{u}}^{L}-\dot{\mathbf{u}}^{S}\right)(6)
$$

と書ける。

この（3）-(6）の 4 つの基礎方程式に基づく理 論体系が線形多孔質媒質理論と呼ばれるものであ る。前章の枠組みに比べると方程式が 3 つ減つ たが，これは変数 $\rho_{L}$ と $\rho_{S}$ が消去されたことと $\phi$ を定数として取り扱うことによるものである。 (3) 式と（4）式はどちらも構成方程式と呼ばれ, 後者が固体フレームワークの構成則を表すのに対 して前者は固液の相対運動の構成則を表すと考え る(e.g., Wang, 2000)。線形多孔質媒質理論で取 り扱われる現象では加速度項が無視できる場合が 多い（波動の問題はその例外）。その場合，(5) 式はダルシー則と呼ばれることが多く，また（6） 式は，(5）式を加えた形で

$$
\nabla \cdot \sigma=0
$$

として用いられることが多い。

固液複合系の波動方程式を導く。(3)-(6) の 4 つの方程式から圧力と応力を消去することによ b,

$$
\begin{aligned}
(1-\phi) & \rho_{S} \ddot{\mathbf{u}}^{S}=P \operatorname{grad} \operatorname{div} \mathbf{u}^{S}-N \operatorname{rot} \operatorname{rot} \mathbf{u}^{S} \\
& +Q \operatorname{grad} \operatorname{div} \mathbf{u}^{L}+\frac{\eta \phi^{2}}{k_{\phi}}\left(\dot{\mathbf{u}}^{L}-\dot{\mathbf{u}}^{S}\right) \\
\phi \rho_{L} \ddot{\mathbf{u}}^{L}= & Q \operatorname{grad} \operatorname{div} \mathbf{u}^{S}+R \operatorname{grad} \operatorname{div} \mathbf{u}^{L} \\
& -\frac{\eta \phi^{2}}{k_{\phi}}\left(\dot{\mathbf{u}}^{L}-\dot{\mathbf{u}}^{S}\right)
\end{aligned}
$$

を得る。P, $Q, R$ は,

$$
\begin{aligned}
& P=K_{b}+\frac{4}{3} N+\frac{\left(1-\phi-\frac{K_{b}}{k_{S}}\right)^{2} k_{S}}{1-\phi-\frac{K_{b}}{k_{S}}+\phi \frac{k_{S}}{k_{L}}} \\
& Q=\frac{\phi\left(1-\phi-\frac{K_{b}}{k_{S}}\right) k_{S}}{1-\phi-\frac{K_{b}}{k_{S}}+\phi \frac{k_{S}}{k_{L}}}
\end{aligned}
$$




$$
R=\frac{\phi^{2} k_{S}}{1-\phi-\frac{K_{b}}{k_{S}}+\phi \frac{k_{S}}{k_{L}}}
$$

である。（8），(9)の $\operatorname{rotをとり~} \Omega_{S}=\operatorname{rot} \mathbf{u}^{S}, \Omega_{L}=$ $\operatorname{rot} \mathbf{u}^{L}$ と置くと

$$
\left\{\begin{aligned}
(1-\phi) \rho_{S} \ddot{\Omega}_{S} & =N \nabla^{2} \Omega_{S}+\frac{\eta \phi^{2}}{k_{\phi}}\left(\dot{\Omega}_{L}-\dot{\Omega}_{S}\right) \\
\phi \rho_{L} \ddot{\Omega}_{L} & =-\frac{\eta \phi^{2}}{k_{\phi}}\left(\dot{\Omega}_{L}-\dot{\Omega}_{S}\right),
\end{aligned}\right.
$$

また（8），(9）の divをとり $e_{S}=\operatorname{div} \mathbf{u}^{S}, e_{L}=$ $\operatorname{div} \mathbf{u}^{L}$ と置くと

$$
\left\{\begin{array}{l}
(1-\phi) \rho_{S} \ddot{e}_{S}=P \nabla^{2} e_{S}+Q \nabla^{2} e_{L}+\frac{\eta \phi^{2}}{k_{\phi}}\left(\dot{e}_{L}-\dot{e}_{S}\right) \\
\phi \rho_{L} \ddot{e}_{L}=Q \nabla^{2} e_{S}+R \nabla^{2} e_{L}-\frac{\eta \phi^{2}}{k_{\phi}}\left(\dot{e}_{L}-\dot{e}_{S}\right)
\end{array}\right.
$$

を得る。

固液複合系における波動伝播の理論はBiot (1956a, b) により与えられた。Biot $(1956 \mathrm{a}, \mathrm{b})$ の理論は均質な系の微小変形のみに限定されたも のであったため, ここではより拡張性のある一般 的枠組みを紹介し, その一つの応用例として波動 を扱った。ここで得た式は $\operatorname{Biot}(1956 \mathrm{a}, \mathrm{b})$ のそ れにほぼ等しいが加速度項に若干の違いがある。 違いが生じた理由は II 章で与えた固体と液体の相 互作用 I にある。II 章では相互作用 $\mathbf{I}$ として液圧 からの寄与と固液の相対速度からの寄与（粘性抵 抗力）を考慮した。これらに加えて, 固液の相対 加速度からの寄与を考慮すると Biot (1956a, b) と全く同じ式を導くことができる。相対速度の寄 与の大きさを決めるパラメー夕が浸透率 $k_{\phi}$ であ るのに対して, 相対加速度の寄与の大きさを決め るパラメータは屈曲度 (tortuosity) と呼ばれ, 流路の折れ曲がりの程度を反映する。

（10）－(11）を解くことにより弾性波速度を求 めることができる。固液複合系の弾性波動は一般 に固体と液体の相対運動を伴い, その結果速度 分散や減衰が生じる。VII 章に示すように，(10)（11）式を用いるとこのような分散と減衰を議論 することができる。しかし，このような分散が生
じる周波数は地震波の周波数帯域 $(\leq 10 \mathrm{~Hz})$ に 比べて十分高いため, 地震波速度という観点から は（10）-(11）の低周波極限における解が特に重 要となる。低周波では速度項の効果が加速度項に 比して大きくなるために, 結果として固液の相対 運動 $\Omega_{L}-\Omega_{S} や e_{L}-e_{S}$ が十分抑えられ, 波の減衰 も無視できる。この場合の縦波と横波の弾性波 速度は, 系の平均密度を $\bar{\rho}=(1-\phi) \rho_{S}+\phi \rho_{L}$ として

$$
\begin{aligned}
& V_{P}=\sqrt{\frac{K_{b}+\frac{4}{3} N+\frac{k s\left(1-K_{b} / k_{S}\right)^{2}}{1-\phi-K_{b} / k_{S}+\phi k_{S} / k_{L}}}{\bar{\rho}}} \\
& V_{S}=\sqrt{\frac{N}{\bar{\rho}}}
\end{aligned}
$$

と求められる。低周波帯域の波動は固液の相対運 動を伴わないため, 浸透率や屈曲度の大きさが弾 性波速度に影響しない。従って，(12)-(13) は Biot（1956a）と一致する。

\section{IV. ポロシティとポア形状}

前章で求まった弾性波速度は, スケルトンの弾 性定数 $K_{b}$ と $N$ に依存する $\left(12-13\right.$ 式)。 $K_{b}$ と $N$ はポロシティのみでなくポアの形状にも大きく依 存する量であり，これらを定量的に予測するため に様々なポア形状を仮定したモデルが開発されて きた（例えば, Mavko et al., 1998)。解析的に解 いたものの中で代表的なものは, oblate spheroid (扁平回転楕円体) のポア形状を仮定したもの（図 $5 \mathrm{a}$ ）、チーブ状のポア形状を仮定したもの（図 $5 \mathrm{~b}$ ), 粒子状の構造を仮定したもの（図 6), 薄い クラック状のポアを仮定したもの，の 4 つが挙 げられる（表 1)。粒子状モデル以外の 3 つは連 続的な固体の中に流体をインクルージョンとして 埋め込んだモデルである。インクルージョンモデ ルでは流体相の連結度が明確にモデル化されてい ないが, 前章で求めた弾性波速度のように, 固液 の相対運動を伴わない現象へ適用する際には流体 の連結度は問題にならない。

ここではポアの向きがランダムに分布したマ 
(a)

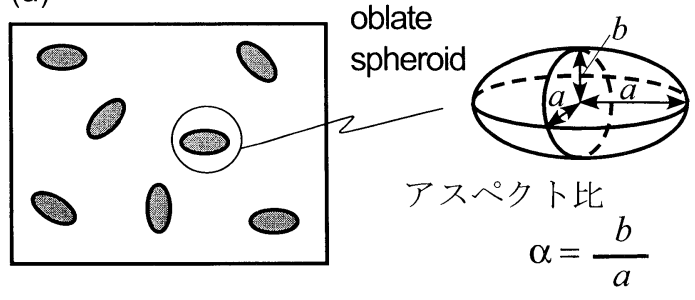

(b)

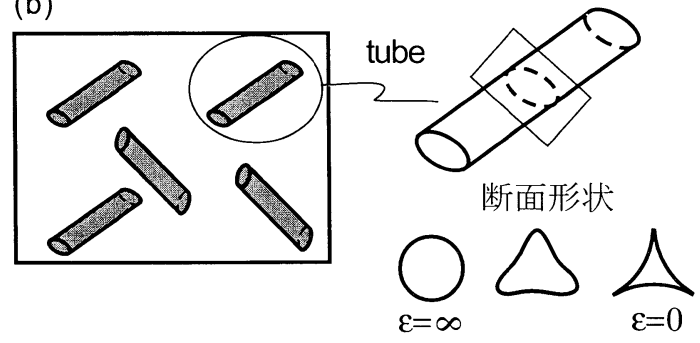

図 5 液体をインクルージョンとして含む固体 のモデル. (a) Oblate spheroid モデル. (b) チューブモデル.

Fig. 5 (a) Oblate spheroid model. (b) Tube model.
クロに異方性のない系のみを考える。 $K_{b}$ と $N$ は, oblate spheroid モデルではポロシティ $\phi$ と oblate spheroidのアスペクト比 $\alpha$ (=短径/長径, 無次元）の関数として, チューブモデルでは $\phi$ と チューブの断面形状を表すパラメータ $\varepsilon$ (無次元) の関数として, 粒子状モデルではコンティギュ イティ $\varphi$ (無次元) の関数として, クラックモデ ルではクラック密度パラメータ (無次元) の関 数としてそれぞれ与えられる。コンティギュイ ティの $\varphi$ 定義は, 各固体粒子がその全表面積のう ちのどれくらいの割合で周囲の粒子と接触して いるかにより与えられる。 $\varphi=0$ は粒子の結合 が全くない状態（固体粒子が液体中に分散した サスペンジョンの状態）に， $\varphi=1$ はポアが全 くない状態に対応する。クラック密度パラメータ $\kappa の$ 定義は, 円形クラックの半径を $a(\mathrm{~m})$, 数密 度を $n\left(\right.$ 個 $\left./ \mathrm{m}^{3}\right)$ とすると， $\kappa=n a^{3}$ で与えられ る。一つのクラックが応力開放する領域の体積が 〜 $a^{3}$ であるので, $\kappa$ の物理的な意味はクラック により応力開放される体積の割合と考えることが

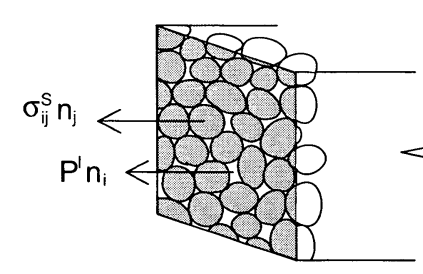

macroscopic stresses

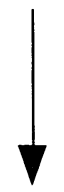

$P^{\prime} n_{i}\left(r^{R}\right) \quad \sigma_{i j}^{C} n_{i}\left(r^{R}\right)$

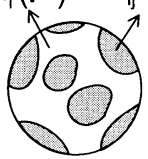

microscopic stress

in a grain
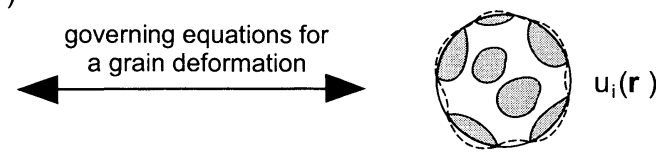

microscopic deformation of a arain

図 6 粒子状物質のマク口な構成則の導出. マク口な応力下で集合体の各粒子 の表面に加わる力を考えて粒子の変形を解き, これに基づいて固体フレー ムワークのマクロな変形を求める.

Fig. 6 Derivation of constitutive relation for a granular material. 
表 1 固液複合系のモデル.

Table 1 Mechanical models for solid-liquid composites.

\begin{tabular}{|c|c|c|}
\hline モデル & 構造のパラメータ（無次元） & 文献 \\
\hline Oblate spheroid & ポロシティ $\phi$, アスペクト比 $\alpha$ & e.g., Berryman $[1980]^{*}$ \\
\hline チューブ & ポロシティ $\phi$, チューブ形状 $\varepsilon$ & Mavko $[1980]$ \\
\hline $\begin{array}{l}\text { 粒子状 } \\
\text { (平衡構造) }\end{array}$ & $\begin{array}{l}\text { コンティギュイティ } \varphi \\
(\text { ポロシティ } \phi, ぬ れ \text { 角 } \theta \text { ) }\end{array}$ & $\begin{array}{l}\text { Takei }[1998] \\
\quad \text { " }\end{array}$ \\
\hline クラック & クラック密度パラメータ $\kappa$ & O'Connell and Budiansky [1974] \\
\hline
\end{tabular}

*:それ以前の文献のタイプエラーが訂正されている

できる。Oblate spheroid モデルとクラックモデ ルは独立に開発されたが, oblate spheroid モデ ルにおいてアスペクト比 $\alpha$ のさい極限をとる と $K_{b}$ と $N$ がクラック密度パラメータ $\kappa=3 \phi /$ $(4 \pi \alpha)$ のみの関数となり，二つのモデルが等価 になることが示されている (Walsh, 1969)。従っ てクラックモデルは oblate spheroid モデルの一 部と考えて良い。

粒子状物質の $K_{b}$ と $N$ をポロシティに結び付け るには，コンティギュイティ $\varphi$ をポロシテイ $\phi に$ 関係付けるモデルが必要になる。土質の分野など では，媒質を弾性球の集合体としてモデル化し， $\phi$ と $\varphi$ 有効封圧によるコンタクト部の弾性変 形から求めることがしばしば行われる（例えば, Duffy and Mindlin, 1957)。しかし数 $100^{\circ} \mathrm{C}$ 以上 の高温の系では，このような弾性的なモデルは現 実的でない。地殼深部や上部マントルの系では, 鉱物単結晶が各固体粒子に対応するので (dry な) 粒界の面積がコンティギュイティを決める。この 時, 粒界のエネルギーが固液界面のエネルギーに 比べて小さい系では, 粒界面積を大きくすること で系の全界面エネルギーを小さくしょうとする作 用が㗢く。系の全界面エネルギーが最小になる時 の構造を平衡構造と呼ぶが, 高温の系では系を平 衡構造へと近づけるための溶解・拡散・析出過程 が十分早く起こるため, このような平衡構造が比 較的容易に実現する。固液界面エネルギー $\gamma_{s l}$ と 粒界エネルギー $\gamma_{s s}$ の相対的な大きさは, 平衡構 造において二つの固液界面がなす二面角 $\theta$ を測定 することにより, $\gamma_{s s} / \gamma_{s l}=2 \cos (\theta / 2)$ と求めら れる（図 7a）。 $\theta$ の大きさは液相による粒界のぬ
れの程度に対応するため, $\theta$ はぬれ角ともよば れる。液体の体積分率 $\phi$ と好角 $\theta$ を与えると 平衡構造を理論的に計算することができ（例え ば, von Bargen and Waff, 1986)，コンティギュ イティを $\phi と \theta$ の関数として求めることができ

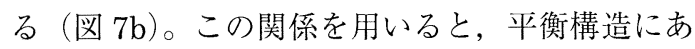
るときの $K_{b}$ と $N$ は $\phi \theta 0$ 関数として求められ る(これを, 平衡構造モデルとよぶ)。一般に岩 石十メルトの系はぬれ角が 20-40位の值をもち, 岩石十水の系は 40-100位の值を持つ（Holness， 1997)。ぬれ角が $60^{\circ}$ 以下の系では，流体は $\phi に$ よらず 3 次元的につながったネットワークを形 成する。チューブモデルも平衡構造をイメージし て開発されたモデルであるが，実験的に測定され るぬれ角 $\theta$ とモデルパラメー夕 $\varepsilon$ を定量的に対応 付けることはできない。

以上のようなモデル化により固液複合系はポロ シティ $\phi$ とポア形状 $x(=\alpha, \varepsilon$, または $\theta)$ の 二つの変数により記述される。ここで重要なの は，ポロシティとポア形状は異なる物理により支 配されているということである。例えば平衡構造 にある系では, ぬれ角は系の温度, 圧力, 化学組 成などの熱力学的条件で決定されるが，ポロシ ティは流体の流れ出しや流れ込みなどの力学的要 因によっても変化する。あるいは，一定体積の水 を含む岩石の変形害験を行った場合には，ポロシ ティは一定であるがポア形状は破壊などにより変 化する。従って, ポロシティもポア形状も未知で あるような地球内部の固液複合系では, 弾性波速 度の観測からポロシティとポア形状を独立に求め ることにより, 対象とする系の置かれている力学 
(a)

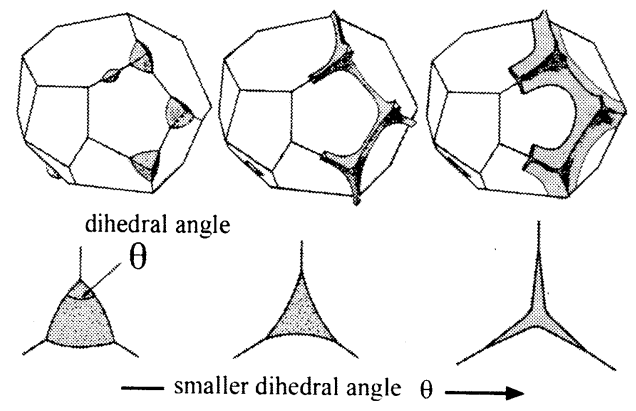

(b)

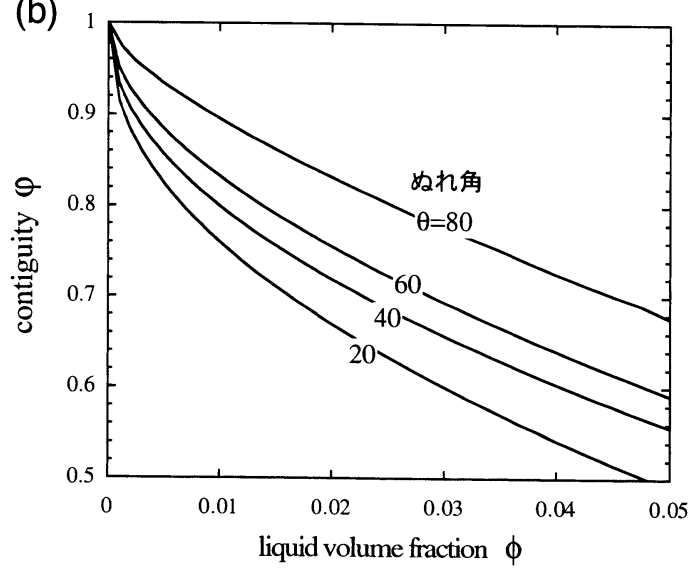

図 7 (a) 系の界面エネルギーを最小にする流体 ポア形状 (平衡構造)。(b) 平衡構造にあ る系のコンティギュイティ. 埆 $\theta$ が小 さいほど液体が粒界をよくめらし（図 7a), コンティギュイティが小さくなる（図 7b),

Fig. 7 (a) Equilibrium geometry of liquid phase characterized by dihedral angle $\theta$. (b) Contiguity versus liquid volume fraction for various dihedral angles.

的状態について貴重な情報を引き出すことができ るのである。

ポア形状を表すパラメータはモデル毎に定義が 異なるため系統的に扱うのが難しいが，以下に述 ベる等価アスペクト比の概念を用いるとポア形状 を系統的に扱うことができる。ポロシティ $\phi$ が比 較的小さい範囲では, $K_{b}$ と $N$ は

$$
\left\{\begin{array}{l}
\frac{K_{b}}{k_{S}}(\phi, x)=1-\phi \Lambda_{K_{b}}(x) \\
\frac{N}{\mu}(\phi, x)=1-\phi \Lambda_{N}(x)
\end{array} \quad(x=\alpha, \varepsilon, \theta)\right.
$$

という $\phi$ の次関数によってよく近似でき（ $\mu$ は 固体本来の剛性率), その比例係数 $\Lambda_{K_{b}}$ と $\Lambda_{N}$ は ポア形状 $x$ によって大きく変わる（図 8)。すな わち， $K_{b}$ と $N$ に対するポロシティとポア形状の 影響は（14）式のように単純に分離することが でき，あるポア形状は力学的には $\Lambda_{K_{b}}$ と $\Lambda_{N}$ とい う二つの量のみで特徴付けられている。このこと は，チューブモデルまたは平衡構造モデルのある $x(=\varepsilon, \theta)$ の值における $\Lambda_{K_{b}}$ と $\Lambda_{N}$ を, oblate spheroid モデルのアスペクト比 $\alpha$ における $\Lambda_{K_{b}}$ と $\Lambda_{N}$ と比較した時に,

$$
\left\{\begin{array}{l}
\Lambda_{K_{b}}(x) \simeq \Lambda_{K_{b}}(\alpha) \\
\Lambda_{N}(x) \simeq \Lambda_{N}(\alpha)
\end{array} \quad(x=\varepsilon, \theta)\right.
$$

を満足するならば，もとのモデルとこのアスペ クト比の oblate spheroid モデルとは常に等し い $K_{b}$ と $N$ を与えるということを意味している。 二つのモデルが $K_{b}$ と $N$ に関して等価であれば, (12)-(13）を用いて計算される $V_{P}$ と $V_{S}$ につい ても常に等価である。（15）式を満たす $\alpha$ を $x$ の 等価アスペクト比と呼ぶ。等価アスペクト比を用 いた 4 つのモデルの関係を図 $9 \mathrm{a}$ に示す。黒と白 のシンボルはそれぞれ $\Lambda_{K_{b}}$ と $\Lambda_{N}$ から求めた等価 アスペクト比を示すが, 両者の差は小さいので等 価アスペクト比がほぼ一つの值に決定できること が分かる。図 9a から，例えばチューブモデルの $\varepsilon=0$ と平衡形状の $\theta=30^{\circ}$ と oblate spheroid モデルの $\alpha=0.1$ は等価なモデルであることが分 かる。等価アスペクト比を用いることでポア形状 の効果を系統的に取り扱うことができる。

（14）式で定義される $\Lambda_{K_{b}}$ と $\Lambda_{N}$ は，厳密には 固体物質本来のポアソン比ンにも依存する。図 8 と図 $9 \mathrm{a}$ に示した結果は, $\nu=0.25$ として計算

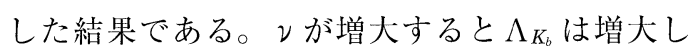
$\Lambda_{N}$ は逆にわずかに減少する傾问がある（例えば, Takei, 1998 の図 4 参照)。この傾向はここに挙 げた全てのモデルについて同様に見られるため, 等価アスペクト比はンによらないとしてよい。 


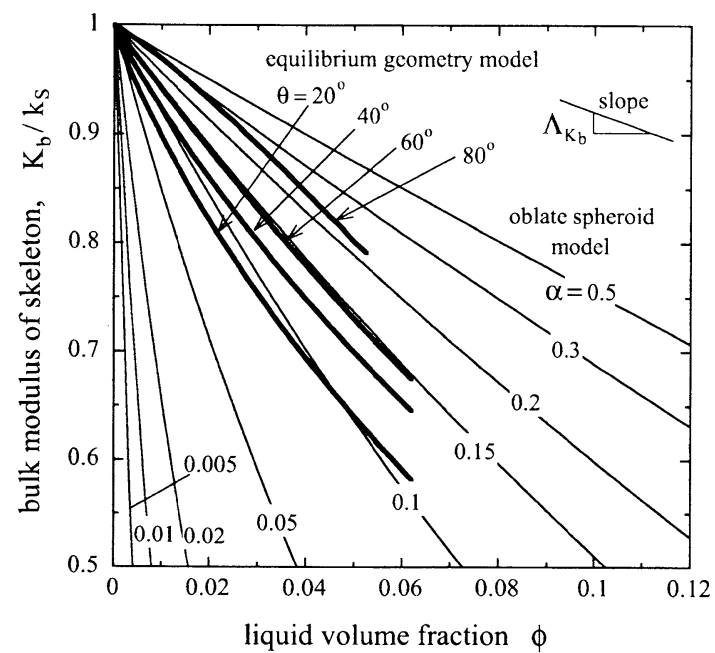

(a)

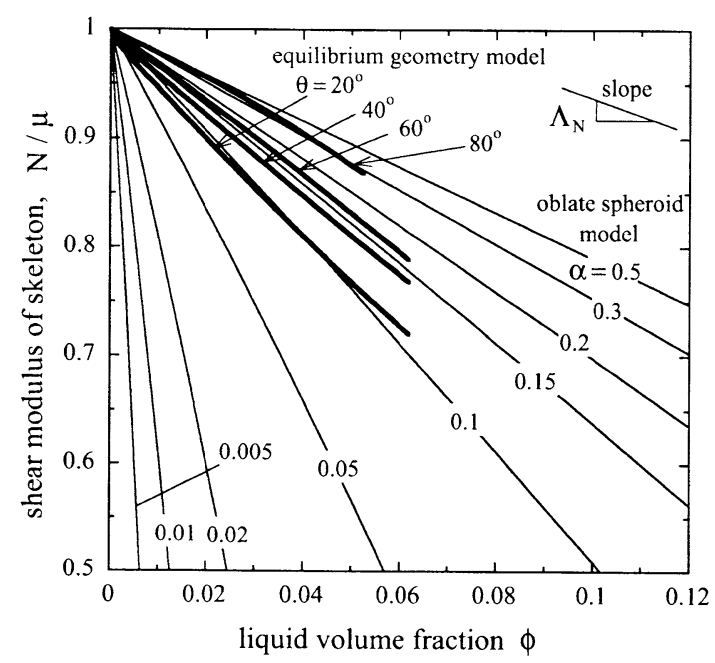

(b)

図 8 スケルトンの（a）体積弾性率 $K_{b}$ 及び（b）剛性率 $N$ とポロシティの関係. 実線は oblate spheroid モデル ( $\alpha$ はアスペクト比), 太線は平衡構造モデル ( $\theta$ はぬれ角). $K_{b}$ と $N$ はポロシティ にほほ比例して減少し，その傾き $\Lambda_{K_{b}}$ と $\Lambda_{N}$ はポア形状に大きく依存する。

Fig. 8 (a) Bulk and (b) shear moduli of solid skeleton versus porosity. $\alpha$ is aspect ratio and $\theta$ is dihedral angle.

\section{V. 固液複合系の弾性波速度}

液体ポアを含む媒質の弾性波速度については, 従来から様々な研究がある。特に, 液体の圧縮率 が $V_{P} / V_{S}$ 比に大きく影響することは良く知られ ている。すなわち，液体ポアはせん断応力を支 えないために $V_{S}$ が低下するが，圧縮率の小さい 液体でみたされていれば圧力は支えるので $V_{P}$ は あまり低下せず， $V_{P} / V_{S}$ 比が増加するのである。 しかし, 液体の圧縮率だけでなく, ポア形状も $V_{P} / V_{S}$ 比に大きく影響することはあまり知られて いない。O'Connell and Budiansky（1974）は, ポアが液体で満たされていない時は $V_{P} / V_{S}$ 比は 低下するが，水で満たされると $V_{P} / V_{S}$ 比が増大 することを示した。一方，Watanabe（1993）は ポアが水で満たされた時は $V_{P} / V_{S}$ 比が低下する がメルト（水より压縮率が小さい）で満たされた 時は $V_{P} / V_{S}$ 比が増大することを示した。ポアが 水で満たされた時の $V_{P} / V_{S}$ 比が前者の研究では 増大するのに後者の研究では低下する理由は，二
つの研究が異なるポア形状を仮定しているからで ある。従って，ポア形状の効果を理解しないと断 片的な知識しか得られない。この章では前章で導 入した等価アスペクト比を用いてポア形状の効果 を系統的に整理し，固液複合系の弾性波速度の全 体像をまとめる。

弾性波速度に対するポア形状の影響はスケルト ンの弾性率 $K_{b}$ と $N$ の中に含まれる $(12-13$ 式)が, それは（14）式によって具体的に表される。（14） 式を（12）-(13）に代入して $\phi$ の 2 次以上の項を 無視すると，

$$
\left\{\begin{array}{l}
\frac{\Delta V_{P}}{V_{P}^{0}}=\left[\frac{\frac{(\beta-1) \Lambda_{K_{b}}}{(\beta-1)+\Lambda_{K_{b}}}+\frac{4}{3} \gamma \Lambda_{N}}{1+\frac{4}{3} \gamma}-\left(1-\frac{\rho_{L}}{\rho_{S}}\right)\right] \frac{\phi}{2} \\
\frac{\Delta V_{S}}{V_{S}^{0}}=\left[\Lambda_{N}-\left(1-\frac{\rho_{L}}{\rho_{S}}\right)\right] \frac{\phi}{2}
\end{array}\right.
$$


(c)

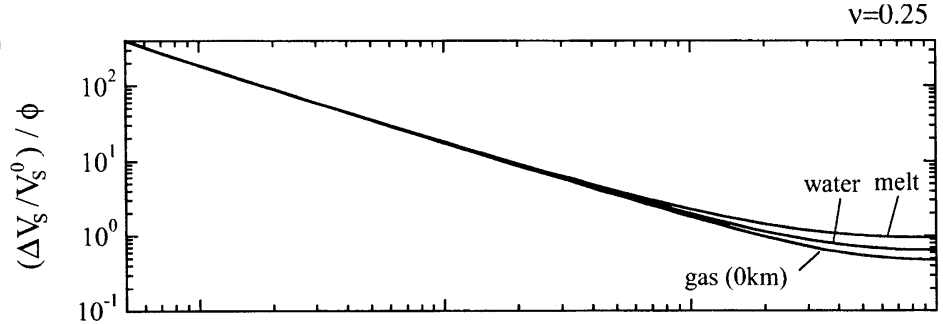

(b)

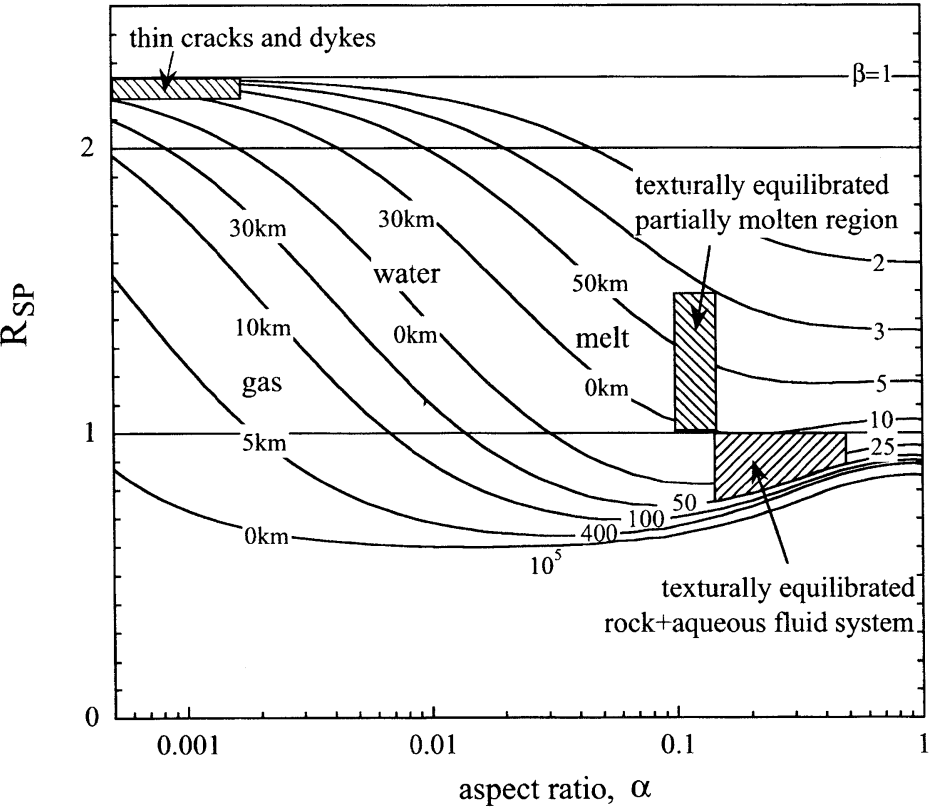

(a)

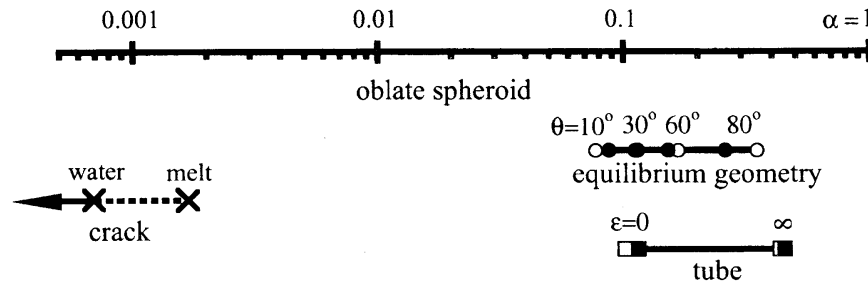

図 9 (a) 平衡構造モデル，チューブモデル，クラックモデルと oblate spheroid モデ ルの関係を等価アスペクト比により示したもの.

黒と白のシンボルはそれぞれ $\Lambda_{K_{b}}$ と $\Lambda_{N}$ から求めた等価アスペクト比を示す。（b) $R_{S P}$ (=横波速度の低下率/縦波速度の低下率) とポアの等価アスペクト比の関係. $\beta=k_{S} / k_{L}$ は岩石 + メトの系で 5-10程度, 岩石 + 水の系で 10-40 程度, 岩石 +理想気体の系で深さ 50-0 km の範囲で 50-10 程度の值をとる. (c) 横波速度 の低下率とポロシティ $\phi$ の比例係数.

Fig. 9 (a) Equivalence of equilibrium geometry model, tube model, and crack model to the oblate spheroid model is shown by the equivalent aspect ratio. Solid and open symbols show the correspondence determined from $\Lambda_{K_{b}}$ and $\Lambda_{N}$, respectively. (b) $R_{S P}$, representing the ratio of fractional changes in $V_{S}$ and $V_{P}$, versus pore aspect ratio $\alpha$, for various $\beta=k_{S} / k_{L}$. (c) Proportional constant between fractional change in $V_{S}$ and porosity versus pore aspect ratio. 
表 2 液体の体積弾性率 $k_{L}$ と $\beta$.

Table 2 Liquid bulk modulus $k_{L}$ and $\beta$.

\begin{tabular}{|c|c|c|c|c|c|}
\hline $\begin{array}{l}\text { depth, } \\
\text { km }\end{array}$ & $\begin{array}{l}\text { 圧力, } \\
\mathrm{GPa}\end{array}$ & $\begin{array}{l}\text { 温度, } \\
{ }^{\circ} \mathrm{C}\end{array}$ & gas & $\begin{array}{l}\mathrm{GPa} \\
\text { water }^{1}\end{array}$ & melt $^{2}$ \\
\hline 0 & $10^{-4}$ & 20 & $\begin{array}{c}1.3 \times 10^{-4} \\
\left(\beta=10^{5}-10^{6}\right)\end{array}$ & $\begin{array}{c}2.2 \\
(18-50)\end{array}$ & $\begin{array}{c}7-25 \\
(4-10)\end{array}$ \\
\hline 5 & 0.15 & 75 & $\begin{array}{c}0.2 \\
(200-600)\end{array}$ & $\begin{array}{c}3.1 \\
(13-40)\end{array}$ & \\
\hline 10 & 0.3 & 150 & $\begin{array}{c}0.4 \\
(100-300)\end{array}$ & $\begin{array}{c}1.8 \\
(22-66)\end{array}$ & \\
\hline 35 & 1 & 500 & $\begin{array}{c}1.3 \\
(30-100)\end{array}$ & $\begin{array}{c}4.5 \\
(9-25)\end{array}$ & \\
\hline 70 & 2 & & & & $\begin{array}{c}20-40 \\
(3-6)\end{array}$ \\
\hline
\end{tabular}

1: Schäfer [1980] のデータを用いた。

2: Stolper et al. [1981] のデー夕を用いた。 $\partial k_{L} / \partial P=6-7$ を仮定.

を得る。ただし， $V_{P}^{0}=\sqrt{\left(k_{S}+4 \mu / 3\right) / \rho_{S}}$ と $V_{P}^{0}=\sqrt{\mu / \rho_{S}}$ は固体本来の弾性波速度を, $\Delta V_{P}=$ $V_{P}^{0}-V_{P}$ と $\Delta V_{S}=V_{S}^{0}-V_{S}$ は速度低下量を表す。 $\beta=k_{S} / k_{L}$ は液体の圧縮率を固体の圧縮率で規格 化した無次元量である。 $\gamma=\mu / k_{S}$ であり， $\gamma$ は 固体物質本来のポアソン比 $\nu$ に依存する。 $\Lambda_{K_{b}}$ と $\Lambda_{N}$ は等価アスペクト比 $\alpha$ の関数であるとしても 一般性を失わない。（16）より，縦波の速度低下 率 $\Delta V_{P} / V_{P}^{0}$ と横波の速度低下率 $\Delta V_{S} / V_{S}^{0}$ は流体の 体積分率に比例し, その比例係数はポア形状や 流体物性に依存することが分かる。ポア形状や流 体物性の違いがこの比例係数を大きく変えるた め, $\Delta V_{P} / V_{P}^{0}$ と $\Delta V_{S} / V_{S}^{0}$ のどちらか一方の情報し かない場合は, ポア形状 $\left(\Delta V_{P} / V_{P}^{0}\right.$ では流体物性 も）が既知でない限り媒質中の流体の体積分率を 決定することはできない。ここでは， $\Delta V_{P} / V_{P}^{0}$ と $\Delta V_{S} / V_{S}^{0}$ の両方が分かっている場合を考え, これ らの情報から流体の体積分率，ポア形状，流体物 性についてどのような制約条件が得られるかを明 らかにする。

まず，縦波の速度低下率と横波の速度低下率の 比を表すパラメータ $R_{S P}$ を導入する。（16）より

$$
\begin{aligned}
& R_{S P}=\frac{\Delta V_{S} / V_{S}^{0}}{\Delta V_{P} / V_{P}^{0}} \\
& =\frac{\Lambda_{N}-\left(1-\frac{\rho_{L}}{\rho_{S}}\right)}{\frac{\frac{(\beta-1) \Lambda_{K_{b}}}{(\beta-1)+\Lambda_{K_{b}}}+\frac{4}{3} \gamma \Lambda_{N}}{1+\frac{4}{3} \gamma}-\left(1-\frac{\rho_{L}}{\rho_{S}}\right)}
\end{aligned}
$$

となり， $R_{S P}$ は $\phi$ に依存せず $\alpha$ と $\beta$ に依存するこ とが分かる。 $R_{S P}<1$ のときは縦波の低下率が 横波の低下率よりも大きいので, $V_{P} / V_{S}$ 比は低 下する。 $R_{S P}>1$ のときは横波の低下率が縦波よ り大きいので, $V_{P} / V_{S}$ 比は増大する。このように $R_{S P}$ は $V_{P} / V_{S}$ 比と密接に関連する量であるが, $R_{S P}$ は $\phi$ に依存しないため $\alpha$ と $\beta$ の効果を調べるには $V_{P} / V_{S}$ 比より見通しが良い。文献によっては $\Delta V_{P, S} /$ $V_{P, S}^{0}$ を $-d \ln V_{P, S}$ と書き, $R_{S P}$ を $d \ln V_{S} / d \ln V_{P}$ と 書くことがある。

図 $9 \mathrm{~b}$ に $R_{S P}$ とポア形状 $\alpha$ の関倸をいろいろな $\beta$ について示す。 $\beta$ は岩石十メルトの系で 5-10 程度, 岩石 + 水の系で 10-40 程度, 岩石 + 理想 気体の系で深さ 50-0 km の範囲で 50-10 5 程度の 值をとる（表 2$) 。 \rho_{L} / \rho_{S}$ の值はメルトが 0.92 , 水が 0.33 , 気体が 0 としたが, $\rho_{L} / \rho_{S}$ の $R_{S P}$ へ 
の影響は小さく, $\rho_{L} / \rho_{S}=1$ と近似しても実用 上問題ない (Takei, 2002, 図 4 参照)。図 9bで ポア形状（等価アスペクト比） $\alpha$ を固定して見る と， $\beta$ が小さいほど（つまり液体の圧縮率が小さ いほど） $R_{S P}$ が大きいことが確認できる。また， $\beta$ が一定であってもポア形状の違いによって $R_{S P}$ が大きく変わることも確認できる。例えば $\beta=$ 25 の線に注目すると，アスペクト比が比較的 大きい $(>0.03)$ 範囲では $R_{S P}$ は 1 より小さい が, $\alpha<0.03$ では $R_{S P}>1$ であり, 非常に薄い ポア $(\alpha<0.0016)$ では $R_{S P}$ が 2 以上の大きな 值を持つ。 $\beta=25$ は岩石十水系に相当する。こ の章の始めに挙げた例で, 岩石 +水系の $V_{P} / V_{S}$ 比 が Watanabe（1993）では減少し O'Connell and Budiansky（1974）では増大したが，これは前 者が $\alpha \sim 0.1$, 後者が $\alpha \sim 0.001$ のポア形状を仮 定したためである。以上のように流体の圧縮率と ポア形状は $R_{S P}$ に対して相対的な役割を果たすの である。

$\Delta V_{P} / V_{P}^{0}$ と $\Delta V_{S} / V_{S}^{0}$ が観測や実験などから得ら れた場合，まずこれらの比をとった $R_{S P}$ を計算す る。存在する流体が何であるかが他の情報から推 測できる場合は， $R_{S P}$ の值から図 $9 \mathrm{~b}$ を用いて等 価アスペクト比を求めることができる。流体が分 からない場合は流体を仮定した上での等価アスペ クト比が求まることになる。眓 $9 \mathrm{c}$ に横波の速度 低下率と $\phi$ の比例係数（(16) の第 2 式）を示す。 求まった等価アスペクト比に対応する比例係数を この図から読み取れば, $\Delta V_{S} / V_{S}^{0}$ の值を用いて $\phi$ が決定できる。図 $9 \mathrm{~b}, \mathrm{c}$ のつの図は, 固液複 合系の弾性波速度に対する流体物性, ポア形状, 流体の体積分率の効果の全体像をまとめた図であ るとともに, 弾性波速度デー夕の逆解析によりこ れらの情報をどの程度知り得るかを具体的に示す 図である。

O'Connell and Budiansky (1974) は $\alpha \sim 0.001$ 程度のクラック状のポアを仮定し, 観測される 様々な $R_{S P}$ の值を水によるクラックの飽和度の 違いで解釈することを提案した。水で満たされた クラックは 2 以上の大きな $R_{S P}$ を与える。一方, ごく浅い領域ならば，空気で満たされたクラック
は 1 より小さい $R_{S P}$ を与える。従って二種類の ポアの比率を様々に変えることで, 中間的な值の $R_{S P}$ を容易に説明できる。しかし，このような解 釈はごく浅い所以外には使えない。理想気体の圧 縮率は圧力に反比例するので, 深い所では理想気 体の圧縮性も水のそれに近づく。地殼深部や上部 マントルの低速度域の $R_{S P}$ を説明するには, 上 述のようにポア形状も変数として考えることが重 要になる。

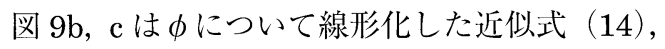
（16），(17）に基づいている。速度低下率と $R_{S P}$ を（12），(13）式から直接計算して近似式の結 果と比べることにより, これらの眓を精度良く 適用できる範囲を求めると, 平衡構造モデルでは $\Delta V_{S} / V_{S}^{0} \leq 0.35$ の範囲で，これは $\phi \leq 0.15$ に相当 する。また, oblate spheroid, チューブ，及び クラックモデルでは $\Delta V_{S} / V_{S}^{0} \leq 0.2$ の範囲である。 平衡構造モデルの適用範囲が広いのは, (14) 式 と（16）式で無視されている $\phi^{2}$ 以上の効果が 互いに打ち消し合うことによる。一方, oblate spheroid, チューブ, 及びクラックモデルでは （14）式の成立する範囲が広い（図 8）ので，簡 単な補正を行えばこれより大きな速度低下につい ても図 9b-c を使用できる（具体的な補正の方法 については Takei（2002）の付録 B を参照)。

\section{VI. 地震波トモグラフィーへの応用}

前章では弾性波速度デー夕の解析法を原理的な 側面から議論した。この章ではその地球科学的意 義や重要性を議論する。

$V_{P}$ と $V_{S}$ のデー夕から求められるポア形状の情 報は等価アスペクト比のみであり, 実際の形が oblate spheroid であるかチューブであるかは原 理的に区別できない。このように解釈が一意でな いものから適切な解釈を引き出して系の真の姿に 迫るためには，地球内部で実現し得るポア形状を 実験や理論により調べてその等価アスペクト比を 求めるというフォーワードアプローチを積み上げ ることが重要になる。地球内部で実現し得るポア 形状について，現状ではぬれ角により決まる平衡 構造（図 7a）と薄いクラックやダイク状という 


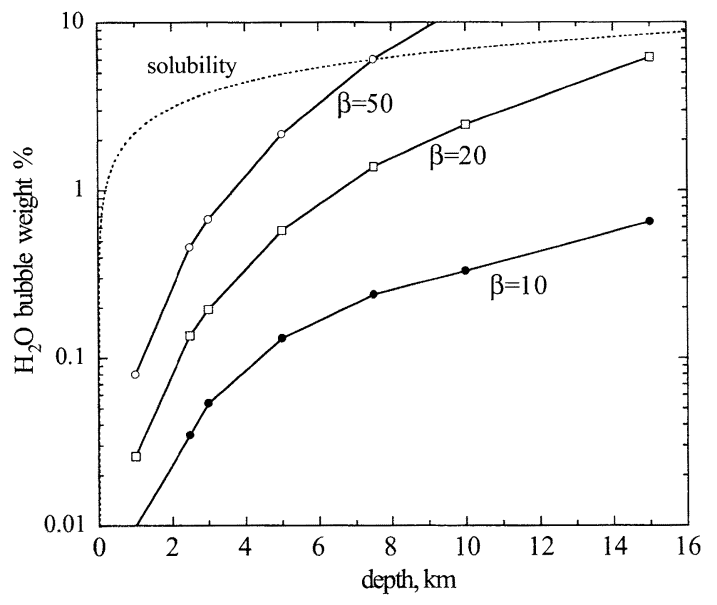

図 10 各深さに拈いて, 岩石十メルトの系の $\beta=k_{S} / k_{L}$ が $10,20,50$ となる時のメル 卜中の気泡の重量\%。気泡は $\mathrm{H}_{2} \mathrm{O}$ からな るとする。参考としてメルト中の水の溶 解度 $(w \%)$ を点線で示す。

Fig. 10 At various depths, the amount of $\mathrm{H}_{2} \mathrm{O}$ bubbles in melt required to obtain $\beta=10,20$, and 50 is shown by weight $\%$.

$2 つ の$ 可能性が実験やフィールド観察から提案さ れている。平衡構造における流体の通路は鉱物粒 子サイズの微小なものであるためその浸透率は小 さい。特に地殼の岩石＋水系は一般にぬれ角が $60^{\circ}$ よりきく，ポアが孤立して浸透率が 0 であ る可能性もある。一方, ダイクやクラックは大き なスケールで発達し得るのでその浸透率は平衡構 造に比べて何桁も大きい可能性がある。従って, 実際の地球内部でどちらの構造が実現しているか ということは，流体の移動速度に大きな影響を与 える。また構造平衡が成立しているかどうかとい うことは, 差応力や変形の程度, 流体の起源など にも重要な示唆を与える。平衡構造とクラックや ダイクでは等価アスペクト比が 2 桁程度異なり得 る（図 9a）ので, 対応する $R_{S P}$ の值は, 岩石 + 水系では前者が 1 以下で後者が 2 以上，岩石 + メルト系では前者が 1-1.5 で後者が 2 以上と大 きく異なり得る（図 $9 \mathrm{~b})$ 。従って $R_{S P}$ によるポア 形状の推定は, 流体の移動様式やテクトニクス を考える上での重要な制約条件になるのである。
Nakajima et al. (2005) はマントルウエッジの 低速度域の $R_{S P}$ から深さによるポア形状の変化 をとらえ, 生成域では平衡構造にあるメルトが上 昇に伴い薄いダイクやクラック状に変化すること を報告した。

東北日本の火山直下数 $\mathrm{km}$ 位には, 低 $V_{P} / V_{S}$ 比の低速度域がしばしば観測される（Nakajima et al., 2003)。岩石 +メルト系は一般に $\beta \leq 10$ で あり， $\alpha$ によず $R_{S P} \geq 1$ が成り立つ（図 $9 \mathrm{~b}$ ）。 従って $V_{P} / V_{S}$ 比の低下はメルトでは説明できな

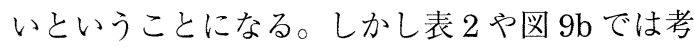
慮されていないが, 数 $\mathrm{km}$ 以浅では, 放出した 揮発性成分（主に水）を気泡として含むメルト が存在する可能性がある。メルトが高温（900$1000^{\circ} \mathrm{C} ）$ のためこのような水は表 2 の水より圧 縮率が大きい。図 10 に, 各哚さにおいてメルト と気泡の混合物の圧縮率が $\beta=10,20,50$ とな るのに必要な気泡 $\left(\mathrm{H}_{2} \mathrm{O}\right.$ からなる）の量を重量\% $(w \%)$ で示した。計算ではメルトは水で飽和し ていると仮定してメルト中の $\mathrm{H}_{2} \mathrm{O}$ 成分の効果も 考慮してあるが，その寄与は大きくない。図 10 より深さ $3-4 \mathrm{~km}$ 程度で $0.2-0.5 w \%$ 程度の水が 放出されていると $\beta=20$ となるが，メルトには もともと数 $w \%$ の水が溶けていると考えられるの でこれは現実にあり得る状況である（図 10 の溶

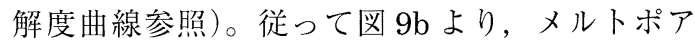
の形によっては十分 $R_{S P}<1$ となることが分か る。もし $V_{P} / V_{S}$ 比の低下がメルト中の気泡の存 在を示しているのであれば, より深部での水の存 在度やマグマ溜まりの進化を考える上での重要な 制約条件となる。ただし，地下数 $\mathrm{km}$ に溜まって いるメルトの粘性は非常に高い可能性があり，VII 章で述べる分散の問題に注意する必要がある。

\section{VII．固液複合系の分散と減衰}

これまでの章で弾性波の速度分散と減衰につい ては詳しく扱わなかったが，章で求めた弾性波 速度が適用できる周波数範囲などを明らかにする 上で重要であるので，この章で簡単なまとめを 行う。初めにIII章の波動方程式から得られる分 散・減衰を横波を例にして紹介する。この分散は 

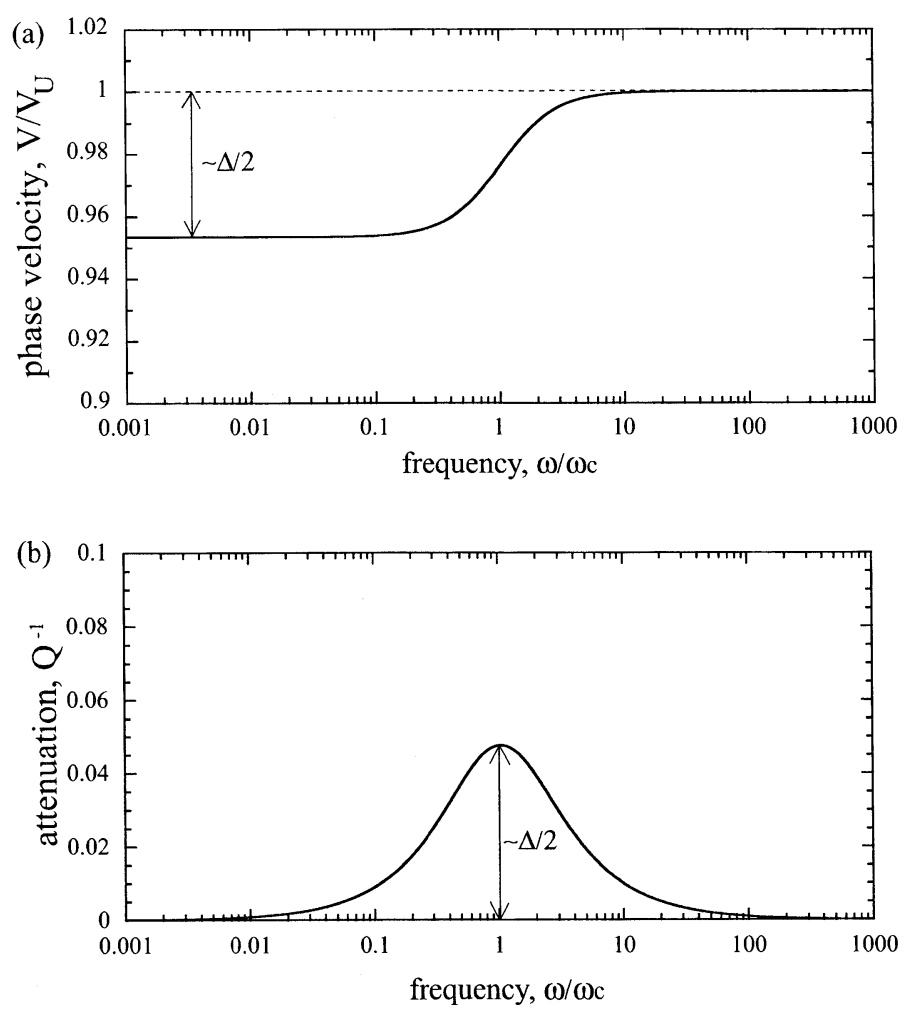

図 11 デバイ方程式が与える（a）位相速度の周波数依存性と, （b）減衰の周波数依存性.

Fig. 11 Frequency dependent phase velocity (a) and $Q^{-1}$ (b) obtained from Debye equations (19).

Biot（1956a, b）により詳しく報告されたのでこ こではBiotメカニズムと呼ぶ。Biotメカニズム の特性周波数は地震波の帯域より十分高く,この 現象が地震波に影響を及ぼす可能性は少ない。し かしここで得られる特徴は, 他の全ての分散・減 衰のメカニズムにおいて共通である。

弾性波の角周波数を $\omega$, 波数を $k$ とする。 (10) の二つの式に $\Omega_{S}=\Omega_{S}^{0} e^{-i(\omega t-k x)}$ と $\Omega_{L}=$ $\Omega_{L}^{0} e^{-i(\omega t-k x)}$ を代入して $\Omega_{S}^{0}=\Omega_{L}^{0}=0$ 以外の解が 存在する条件を求めると, 分散関係

$$
\left(\frac{k}{\omega}\right)^{2}=\frac{\rho_{U}}{N} \cdot f(\omega)
$$

を得る。 $f(\omega)$ は周波数に依存する複素数で,

$$
\begin{gathered}
f(\omega)=f_{1}(\omega)+i f_{2}(\omega) \text { とおくと } \\
\left\{\begin{array}{l}
f_{1}(\omega)=1+\frac{\Delta}{1+\left(\frac{\omega}{\omega_{c}}\right)^{2}} \\
f_{2}(\omega)=\frac{\Delta \cdot\left(\frac{\omega}{\omega_{c}}\right)}{1+\left(\frac{\omega}{\omega_{c}}\right)^{2}}
\end{array}\right.
\end{gathered}
$$

と書ける。ただし $\rho_{U}=(1-\phi) \rho_{S}, \quad \rho_{R}=$ $(1-\phi) \rho_{S}+\phi \rho_{L}, \quad \Delta=\left(\rho_{R}-\rho_{U}\right) / \rho_{U}, \quad \omega c=$ $\eta \phi /\left(k_{\phi} \rho_{L}\right)$ である。位相速度 $V$ と減衰 $Q^{-1}$ は $k / \omega=V^{-1}(1+i /(2 Q))$ と与えられ, $f_{2} \ll f_{1}$ にお いて 


$$
\left\{\begin{array}{l}
V=\sqrt{\frac{N}{\rho_{\mathrm{U}} \cdot f_{1}(\omega)}} \\
Q^{-1}=\frac{f_{2}(\omega)}{f_{1}(\omega)}
\end{array}\right.
$$

\section{と計算できる。}

図 11 に位相速度 $V$ と減衰 $Q^{-1}$ を規格化周波 数 $\omega / \omega_{c}$ の関数として示した。 $\omega / \omega_{c}=1$ の近 傍で $V$ の周波数依存性（すなわち，分散）が生 じる。この原因は， $\omega / \omega_{c} \gg 1$ では液体が固体 フレームワークの運動に追従できずに自らの慣性 で静止しており， $\omega / \omega_{c} \ll 1$ では固液界面を通 した粘性カップリングが十分作用して液体が固体 の連動に良く追従することによる。従って（18） 式で $\rho_{U} f(\omega)$ を密度と考えると理解しやすい。 即ち, 高周波側の密度は固体の質量のみで決ま る密度 $\rho_{U}$ なので $V_{U}=\sqrt{N / \rho_{U}}$ となり, 低周波 側の密度は液体の質量も含めた $\rho_{R}=\bar{\rho}$ なので $V_{R}=\sqrt{N / \rho_{R}}$ となるのである。減衰 $Q^{-1}$ は $\omega=$ $\omega_{c}$ で最大值をとり，その大きさは

$$
Q_{M A X}^{-1}=\frac{\Delta}{2+\Delta} \simeq \frac{\Delta}{2}
$$

と与えられる。特性周波数 $\omega_{c}$ は砂岩 + 水で $200 \mathrm{kHz} \quad\left(k_{\phi}=10^{-12} \mathrm{~m}^{2}, \eta=10^{-3} \mathrm{Pas}, \quad \rho_{L}=\right.$ $\left.10^{3} \mathrm{~kg} / \mathrm{m}^{3} ， \phi=0.2\right)$ と見積もられる。一般の $k_{\phi}$ はこれより小さいと考えられるので， $\omega_{c}$ は地 震波の带域より十分高周波にあるといえる。同様 の分散は縦波（11式）にもあるが, ここでは扱 わない。

（19）はデバイ方程式と呼ばれ個々のメカニズ ムによらず全ての分散・減衰に普遍的に現れる (Nowick and Berry, 1972)。時刻 $t \geq 0$ に一定の 単位力を加えたとき，その応答 $J(t)$ が指数関 数的な時間遅れを伴って

$$
J(\iota)-J_{U}\left[1+\Delta \cdot\left(1-e^{-\omega_{t} t}\right)\right] \cdot H(t)
$$

と与えられる時，これを緩和現象（relaxation） と呼ぶ。 $H(t)$ はへビサイド関数である。 $J_{U}$ を 非緩和時の応答 (unrelaxed), $J_{U}(1+\Delta)=$
$J_{R}$ を緩和時の応答 (relaxed), $\Delta$ を緩和強度, $\omega_{c}^{-1}$ を緩和の時定数と呼ぶ。インパルスレスポ ンスは $(22)$ を一階微分した $\dot{J}=J_{U}[\delta(t)+$ $\left.\omega_{c} \Delta e^{-\omega_{t} t} H(t)\right]$ であるが, $\dot{J} / J_{U}$ のフーリ工変換 がデバイ方程式（19）に他ならない。即ち，デ バイ方程式は（22）のような緩和現象を周波数 領域で見た時に普遍的に現れる式なのである。媒 質の密度や弾性定数を変化させる緩和過程が存在 していると，その時定数に対応する周波数的で 弾性波の分散が生じる。これより十分高周波では 緩和が生じないので $J_{U}$ が観測され，減衰もない。 十分低周波では緩和は準静的に（平衡状態からの 大きなずれを伴わずに）生じるため減衰はなく, $J_{R}$ が観測される。 $\omega=\omega_{c}$ 付近では非平衡下での 緩和が起こり減衰が生じる。 $Q_{M A X}^{-1}$ は緩和強度 $\Delta$ で決まる。

固液複合系には流体が原因で生じる緩和現象が ある。上述したBiotメカニズムはその一つであ り，密度が $\rho_{U}$ から $\rho_{R}$ に緩和する現象として捉 えることができる。一方，固体フレームワークの 弾性定数を緩和する現象に「squirt flow」がある (Mavko and Nur, 1975)。この現象の実体は，ポ ア間の液圧不均質が液体の粘性流動で緩和される ことである。アスペクト比が 1 よりさいポア を含む媒質にせん断応力が加わると，ポアの向 きにより大きさと符号の異なる液圧変化が生じ る。異なるアスペクト比のポアを含む媒質であれ ば，等方的な応力が加わった場合でも液圧不均質 を生じる。液圧不均質はポア間で液体の流れが生 じると緩和されるが，これに伴って固体フレーム ワークの弾性歪みが変化し, 弾性定数が $M_{U}$ から $M_{R}$ に変化する $\left(M_{U}>M_{R}\right)$ 。 $\left(M\right.$ は $K_{b}$ または $N$ を表す。）メカニズムから分かるように, squirt flow は体積弾性率よりも剛性率に大きく影響し, 従って $V_{P}$ よりも $V_{S}$ に大きく影響する。II 章で 紹介した理論では, 液圧は平均化されたものの みを考慮し，ポア間の液圧の不均質は考慮され ていない。従って, squirt flowの緩和された状 態（relaxed）を仮定したことになる。アスペク 卜比 $\alpha$ が比較的大きい範囲では，生じる液圧不均 質がわずかなので緩和強度が小さく, relaxed と 
unrelaxed の違いはあまり問題にはならない。し かし $\alpha$ が小さいところでは剛性率の緩和強度が大 きいためこの仮定が成立しているかどうかが重要 である。この仮定が成り立つためには，ポアが連 結していて, かつ, 波の周波数が squirt flow の 特性周波数 $\omega_{c}=k_{S} \alpha^{3} / \eta \quad\left(\mathrm{O}^{\prime}\right.$ Connell and Budiansky，1977）に比べて低いことが必要である。 $k_{S} \sim 10^{10}-10^{11} \mathrm{~Pa}$ であるので, 水 $\left(\eta=10^{-3} \mathrm{~Pa} \mathrm{~s}\right)$ やバサルトメルト $\left(1-10^{3} \mathrm{~Pa} \mathrm{~s}\right)$ ではアスペク 卜比 $\alpha$ が小さい $\left(<10^{-2}-10^{-3}\right)$ 時に $\omega_{c}$ が地震 波带域に近づく。またポアの向きがランダムでな い場合には，緩和時であってもせん断応力が液圧 変化を伴うことがあり， $V_{S}$ に影響を与える。従っ て，II章で導いた $V_{P}$ と $V_{S}$ を $\alpha$ が小さい所に応 用する際には, ポアの連結度, squirt flow の時 定数, 及びポアの向きのランダムさに注意する必 要がある。

流体の圧縮率 $k_{L}$ を緩和する現象もある。メル ト中の気泡を圧縮するためには, メルトの粘性流 動による緩和が必要である（特に, 気泡が球形の 場合)。眓 10 に示したのはこのような緩和が十 分起こった時（relaxed）の結果である。高粘性 のデイサイトメルトの場合は地震波帯域がこの時 定数に近づいたり unrelaxedになったりする可 能性がある（市原, 1997, 図 5.6 参照）ので注意 が必要である。

\section{VIII. おわりに}

本総説では，固液複合系の弾性波速度に対する 流体の体積分率, ポア形状, 流体物性の影響につ いて，主に原理的側面からまとめを行った。地震 波トモグラフィーなどに応用する際の現実的な問 題は詳しく扱わなかった。現実的な問題で考慮す べきこととしては，(1）ポアの向きに異方性があ る場合，（2）流体の粘性による速度分散・減衰, （3） $V_{P}^{0}$ と $V_{S}^{0}$ の推定，（4）流体ポア以外の要因 による地震波速度低下，などが挙げられる。VII章 に述べたように，薄いクラックやダイク状のポ アを考える場合には，(1）と（2）の可能性を念 頭においたさらにきめ細かい議論が重要になる。 （3）は（4）と密接に関連する。本総説で紹介し
た理論を応用する際には, 固体本来の弾性波速度 $V_{P}^{0}$ と $V_{S}^{0}$ は低速度域の温度 ·圧力条件下で, しか も地震波の周波数帯域で推定する必要がある。高 温高压下での弾性定数のデータはまだ十分ではな く, しかもほとんどが超音波带域に限られる。上 部マントルは比較的均質なため, 流体が存在しな いと思われる領域の地震波速度データを $V_{P}^{0}$ と $V_{S}^{0}$ の推定に用いることもできる。しかしその場合で も低速度域が周囲より高温であれば温度による低 下分を考慮する必要があり, 地震波帯域での温度 効果の見積もりにはまだ不確定性が大きいのであ る。流体相について正しい情報を得るためには流 体以外の要因の不確定性を減らすことが重要であ り, 温度効果の見積もりに不確定性を生じている 粒界すべりなどの（メルトの関与しない）緩和過 程の解明や, 緩和現象への直接的な制約条件とな る $Q^{-1}$ 構造の解明などが重要になる。

\section{謝 辞}

II 章で扱った内容は, 東大地震研で 01-02 年度に開 催された「青い地球の地震学セミナー」にて参加者全員 で議論した内容が基になっている。また本総説をまと める際に, 小屋口剛博さん, 中島淳一さんに有益な議 論を頂いた。西澤 修さんには本総説を書くことを勧 めて頂いた。この場を借りて感謝したい。

\section{文献}

Berryman, J.G. (1980): Long-wavelength propagation in composite elastic media 2 : Ellipsoidal inclusions. J. Acoust. Soc. Amer., 68, 1820-1831.

Biot, M.A. (1956a): Theory of propagation of elastic waves in a fluid-saturated porous solid, 1 , Lowfrequency range. J. Acoust. Soc. Amer., 28, 168-178.

Biot, M.A. (1956b): Theory of propagation of elastic waves in a fluid-saturated porous solid, 2, Higher frequency range. J. Acoust. Soc. Amer., 28, 179-191.

Drew, D.A. (1983): Mathematical modeling of twophase flow. Ann. Rev. Fluid Mech., 15, 261-291.

Duffy, J. and Mindlin, R.D. (1957): Stress-strain relations and vibrations of a granular medium. J. Appl. Mech., 24, 585-593.

Holness, M.B. (1997): Surface chemical controls on pore-fluid connectivity in texturally equilibrated materials. Jamtveit, B. and Yardley, B. eds.: Fluid Flow and Transport in Rocks. Chapman and Hall, 149-169.

Ichihara, M. (1997): 気泡を含む粘弾性流体の力学 : マ グマのダイナミクスへの応用. 東京大学博士論文. 
Kuster, G.T. and Toksöz, M.N. (1974): Velocity and attenuation of seismic waves in two-phase media, 1 , Theoretical formulations. Geophysics, 39, 587-606.

McKenzie, D. (1984): The generation and compaction of partially molten rock. J. Petrol., 25, 713-765.

Mavko, G.M. (1980): Velocity and attenuation in partially molten rocks. J. Geophys. Res., 85, 5173-5189.

Mavko, G. M. and Nur, A. (1975): Melt squirt in the asthenosphere. J. Geophys. Res., 80, 1444-1448.

Mavko, G., Mukerji, T. and Dvorkin, J. (1998): The Rock Physics Handbook. Cambridge Univ. Press, New York.

Nakajima, J. and Hasegawa, A. (2003): Tomographic imaging of seismic velocity structure in and around the Onikobe volcanic area, northeastern Japan: Implications for fluid distribution. J. Vol. Geotherm. Res., 127, 1-18.

Nakajima, J., Matsuzawa, T., Hasegawa, A. and Zhao, D. (2001a): Three-dimensional structure of $\mathrm{Vp}, \mathrm{Vs}$, and $\mathrm{Vp} / \mathrm{Vs}$ beneath northeastern Japan: Implications for arc magmatism and fluids. J. Geophys. Res., 106, 21843-21857.

Nakajima J., Matsuzawa, T., Hasegawa, A. and Zhao, D. (2001b): Seismic imaging of arc magma and fluids under the central part of northeastern Japan. Tectonophysics, 341, 1-17.

Nakajima, J., Takei, Y. and Hasegawa, A. (2005): Quantitative analysis of the inclined low-velocity zone in the mantle wedge of northeastern Japan: A systematic change of melt-filled pore shape with depth and its implications for melt migration. Earth Planet. Sci. Lett., 234, 59-70.

Nowick A.S. andBerry, B.S. (1972): Anelastic Relaxation in Crystalline Solids. Academic Press, New York.

Obara, K. (2002): Nonvolcanic deep tremor associated with subduction in Southwest Japan. Science, 296, 1679-1681.

O'Connell, R. J. and Budiansky, B. (1974): Seismic velocities in dry and saturated cracked solids. J. Geophys. Res., 79, 5412-5426.

O'Connell, R. J. and Budiansky, B. (1977): Viscoelas- tic properties of fluid-saturated cracked solids. $J$. Geophys. Res., 82, 5719-5735.

Ohmi, S. and Obara, K. (2002): Deep low-frequency earthquakes beneath the focal region of the Mw 6.7 2000 Western Tottori Earthquake. Geophys. Res. Lett., 29, doi:10.1029/2001GL014469.

Schäfer, K. ed. (1980): Landolt-Börnstein Numerical Data and Functional Relationships in Science and Technology. New Series IV, Volume 4, HighPressure Properties of Matter, Springer-Verlag.

Stolper, E., Walker, D., Hager, B.H. and Hays, J.H. (1981): Melt segregation from partially molten source regions: The importance of melt density and source region size. J. Geophys. Res., 86, 6261-6271.

Takei, Y. (1998): Constitutive mechanical relations of solid-liquid composites in terms of grain-boundary contiguity. J. Geophys. Res., 103, 18183-18203.

Takei, Y. (2002): Effect of pore geometry on $\mathrm{Vp} / \mathrm{Vs}$ : From equilibrium geometry to crack. J. Geophys. Res., 107, doi:10.1029/2001JB000522.

Tsumura, N., Matsumoto, S., Horiuchi, S. and Hasegawa, A. (2000): Three-dimensional attenuation structure beneath the northeastern Japan arc estimated from spectra of small earthquakes. Tectonophysics, 319, 241-260.

von Bargen, N. and Waff, H.S. (1986): Permeabilities, interfacial areas and curvatures of partially molten systems: Results of numerical computations of equilibrium microstructures. J. Geophys. Res., 91, 9261-9276.

Walsh, J. B. (1969): New analysis of attenuation in partially melted rock. J. Geophys. Res., 74, 43334337.

Wang, H.F. (2000): Theory of Linear Poroelasticity with Applications to Geomechanics and Hydrogeology. Princeton University Press.

Watanabe, T. (1993): Effects of water and melt on seismic velocities and their application to characterization of seismic reflectors. Geophys. Res. Lett., 20, 2933-2936.

(2005 年 8 月 3 日受付, 2005 年 11 月 18 日受理) 